\title{
Some Biological Studies and Gonadal Development of Rabbitfish Siganus canaliculatus (Park) and Siganus spinus L. (F: Siganidae) from the Gulf Waters off Saudi Arabia
}

\author{
Elham A. WasseF 1 and Hayam Abdul Hady \\ National Institute of Oceanography and Fisheries, \\ Kayed Bey, Alexandria, Egypt
}

\begin{abstract}
Aвstract. Three species of rabbitfishes (F: Siganidae) are recorded in the Saudi Arabian Gulf waters near Dammam, of which Siganus canaliculatus (Safi Arabi) is the most common and commercially important. Knowledge on two morphometric characters, namely: body depth and standard length of $S$. canaliculatus and S. spinus are given. Condition factor, weight/length relationship and gonad development of the former species are thoroughly described, which could serve as a basis for the near future mariculture practices of the species in the area.
\end{abstract}

\section{Introduction}

Rabbitfish or siganids are widely distributed and are considered as excellent food fishes (Lam, 1974). The mariculture potential of rabbitfish were pointed out in many parts of the world (Lam, 1974; Baga and Sacayanan, 1980; Al Aradi et al., 1985; Bwathondi, 1986; Pillay, 1990; Nelson et al., 1992 \& Al Ghais, 1993). Seven siganus species are recorded in Red Sea and Arabian Gulf waters off Saudi Arabia, which are locally known as "Sigan" in the former region and "Safi" in the latter (Daghestani et al., 1988). Three species are reported along the Saudi Gulf coast, namely: Siganus canaliculatus Park or whitespotted spinefoot, (Local name, Safi Arabi), $S$. javus L. or streaked spinefoot (Safi Sunaifi) and $S$. spinus L. or Dusky spinefoot. The first species is the most common and economically important whereas the second one was less common in the commercial catch during the investigation period and the third was relatively smaller in size.
The successful trials made to culture $S$. canaliculatus indicated that they grow up to about $80 \%$ of their adult size in 6 months and reach maturity in one year (Al Aradi et al., 1985, Bwathondi, 1986 \& Al Ghais, 1993). In Saudi Arabia culture of Siganus rivulatus in cages and ponds in the Red Sea coast were very promising (Thobaity et al., 1984 and Bukhari et al., 1989). Much interest has recently arisen in the mariculture of siganid fishes in the Arabian Gulf area by studying the different biological characteristics of the species (Al Ghais, 1993; El Sayed and Bary, 1994, Wassef and Abdul Hady, 1996, 97 \& 99). Reproductive biology of S. canaliculatus has been dealt with (Wassef and Abdul Hady, 1997) but no detailed description of the gonadal development has been made.

The objective of the present study is to provide further information on $S$. canaliculatus which has practical utility for larvae production in hatcheries, and may be useful for siganid culture in Saudi Arabia and similar areas.

${ }^{1}$ Corresponding author, Fax: (203) 4801 174, email: elel@link.net. 


\section{Material and Methods}

Regular investigation for $S$. canaliculatus and $S$. spinus, in the commercial catch of Dammam markets was conducted during January to December 1997. Fish samples were taken at monthly intervals and examined for total and standard length (TL \& SL, mm), body depth $(B D, \mathrm{~mm})$ total and gutted weights $(\mathrm{g})$ for both species. Additional samples of $S$. canaliculatus were also taken fortnightly around the spawning season, April-June (Wassef and Abdul Hady, 1997). Total length varied between $15 \& 43 \mathrm{~cm}$ for the former species and $14-27 \mathrm{~cm}$ for the latter. S. canaliculatus maturity stage was assigned visually using a six-stage scale (Wassef and Abdul Hady, 1997). Gonads (ovaries and testes) were carefully removed, weighed (mg) and fixed in 5\% neutral formalin, dehydrated in graded ethanol series and embeded in Parafin wax. Tissues were sectioned at $4 \mu \mathrm{m}$ for male and 6-8 $\mu \mathrm{m}$ for female, and stained in Eosin and Hematoxylin (Bancroft and Stevens, 1982). Terminology used for description of the different stages of oocyte growth follows that of Yamamoto 1956a, (Loc. cited West, 1990).

The weight/length relationship of $S$. canaliculatus was calculated from the logarithms of total length $(L, \mathrm{~cm})$ and actual weight $(W, \mathrm{~g})$ (Beckman, 1948). Total or gutted weight was used in calculating the condition factor $(K)$ of fish as follows : $K=$ $100 \mathrm{~W} / \mathrm{L}^{3}$ (Niklosky, 1963). Total weights were used only to calculate a mean $K$ value for combined sexes monthly and seasonally.

Morphometric index $(R I)$ was calculated as a percentage ratio of each morphometric measurement to total fish length. The mean corresponding $R I$ for each length group was then obtained for both males and females $S$. canaliculatus and S. spinus.

Regression analyses were applied to represent the relationship between either body depth or standard length, on one hand and total length on the other hand for both species. One-way analysis of variance (ANOVA) was applied to test the significance of sex variability (Snedecor and Cochran, 1980).

\section{Results}

\section{Morphometry}

Comparative Morphometric Characters of S. canaliculatus and S. spinus
In the present work, more emphasis has been put on three morphometric characters namely body depth $(B D)$, standard length $(S L)$ and condition factor $(K)$.

\section{Ratio Indices}

Body Depth Ratio Index (BDI). Examination of body depth ratio indices (BDI) for $S$. canaliculatus according to fish length groups for separate sexes (Table 1) shows that the range and mean values are not significant $(\mathrm{P}<0.05)$ between sexes. For combined sexes it is clear that $B D I$ values remain about constant with fish length variation (Fig. 1a). $B D I$ range and mean (36.3) values for $S$. spinus are higher than the corresponding for $S$. canaliculatus (33.1) (Table 2 \& Fig 1a). These values identify each species in the area of investigation. For $S$. spinus longer than $20 \mathrm{~cm}, B D I$ values increased slightly with the increase of fish length (Fig 1a).

TABLE 1. Ratio indices range and means for $S$. canaliculatus from Dammam waters of Arabian Gulf (between brackets are the number of fish analyzed).

\begin{tabular}{|c|c|c|c|}
\hline Ratio index & Sex & Range & Mean $(\mathrm{cm}) \pm$ s.d. \\
\hline \multirow{3}{*}{$B D / T L$} & $\begin{array}{c}\mathrm{M} \\
(1056)\end{array}$ & $32.29-33.56$ & $32.98^{*} \pm 0.4$ \\
\cline { 2 - 4 } & $\begin{array}{c}\mathrm{F} \\
(967)\end{array}$ & $32.37-34.63$ & $33.27^{*} \pm 0.5$ \\
\cline { 2 - 4 } & $\mathrm{M}+\mathrm{F}$ & $32.29-34.63$ & $33.16 \pm 0.3$ \\
\hline \multirow{5}{*}{$S L / T L$} & $\begin{array}{c}\mathrm{M} \\
(1056)\end{array}$ & $74.19-77.51$ & $75.69^{*} \pm 0.8$ \\
\cline { 2 - 4 } & $\begin{array}{c}\mathrm{F} \\
(967)\end{array}$ & $74.27-77.83$ & $75.55^{* *} \pm 0.9$ \\
\cline { 2 - 4 } & $\mathrm{M}+\mathrm{F}$ & $74.19-77.83$ & $75.73 \pm 0.8$ \\
\hline
\end{tabular}

$B D$ body depth, $S L$ standard length, $T L$ total length, s.d. standard deviation, $\mathrm{M}$ males, $\mathrm{F}$ females.

*not significant at $\mathrm{P}<0.05$.

Standard Length Ratio Index (SLI). From Table 1 it is obvious that mean $S L I$ values for females (75.6) and males (75.7) S. canaliculatus are more or less the same. Sex variation was proved insignificant $(\mathrm{P}<0.05)$ therefore mean $S L I$ for sexes combined were calculated (Table 2), which showed a decreasing trend with the increase of total fish length (Fig 1b). Comparable results for S. spinus revealed similar trend. SLI values for $S$. spinus are 


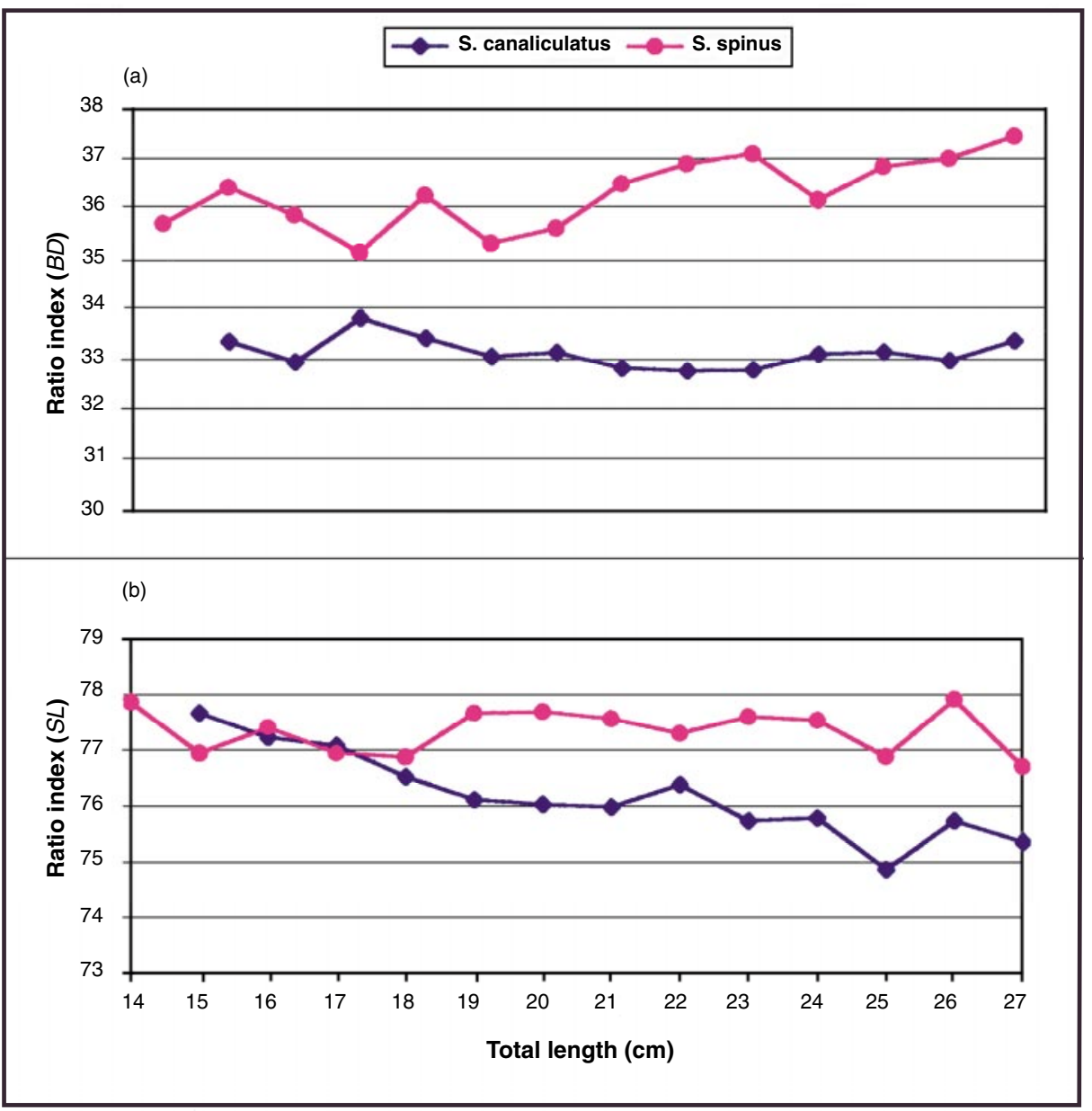

FIG. 1. Variations of ratio indices (R.I.) of body depth (a) and standard length, (b) with total fish length for S. canaliculatus and S. spinus.

TABLE 2. Range and mean of two morphometric ratio indices $(B D \& S L)$ for both $S$. canaliculatus and $S$. spinus (combined sexes).

\begin{tabular}{|c|c|c|c|c|}
\hline \multirow{2}{*}{ Morphometric ratio index } & \multicolumn{2}{|c|}{ S. canaliculatus } & \multicolumn{2}{|c|}{ S. spinus } \\
\cline { 2 - 5 } & Index range & Mean \pm s.d.* & Index range & Mean \pm s.d. \\
\hline$B D / T L$ & $32.29-34.63$ & $33.16 \pm 0.3$ & $35.14-37.47$ & $36.32 \pm 0.7$ \\
$S L / T L$ & $74.19-77.83$ & $75.73 \pm 0.8$ & $76.71-77.86$ & $77.36 \pm 0.4$ \\
\hline
\end{tabular}

*s.d. = standard deviation,

$B D$ body depth, $S L$ standard length, $T L$ total length.

always higher than that for $S$. canaliculatus of the same length group (Fig 2b).

\section{Morphometric Regressions}

The observed values of either body depth $(B D)$ or standard length $(S L)$, were firstly plotted against total fish length $(T L)$ as scatter diagrams in which a clear linear relationship existed in all cases. Consequently, the following regression equations were computed for $S$. canaliculatus to adequately represent the correlation between the morphometric character and total fish length :

$$
\begin{array}{lll}
B D_{m}=0.3323+0.3451 & T L_{m}(r=0.9986) & \text { for males } \\
B D_{f}=0.1151+0.3384 & T L_{f}(r=0.9983) & \text { for females } \\
S L_{m}=0.7990+0.7204 & T L_{m}(r=0.9996) & \text { for males } \\
S L_{f}=0.7432+0.7272 & T L_{f}(r=0.9996) & \text { for females }
\end{array}
$$

Sex variations found to be insignificant $(\mathrm{P}<$ $0.05)$ therefore, one equation was derived for each species (Table 3). 
TABLE 3. Comparison of morphometric regressions of standard length and body depth for S. canaliculatus and S. spinus.

\begin{tabular}{|c|c|c|c|c|c|}
\hline S. canaliculatus & $\mathrm{r}^{2 *}$ & $\mathrm{~N}^{* *}$ & S. spinus & $\mathrm{r}^{2}$ & $\mathrm{~N}$ \\
\hline$B D=0.1515+0.3238$ T.L. & 0.9979 & 2023 & $B D=-0.3086+0.3806$ T.L. & 0.9883 & 100 \\
$S L=0.7208+0.7258$ T.L. & 0.9989 & 2023 & $S L=0.2370+0.7587$ T.L. & 0.9976 & 100 \\
\hline
\end{tabular}

$\mathrm{r}^{*}=$ Correlation of coefficient

$\mathrm{N}^{* *}=$ Number of fish analyzed
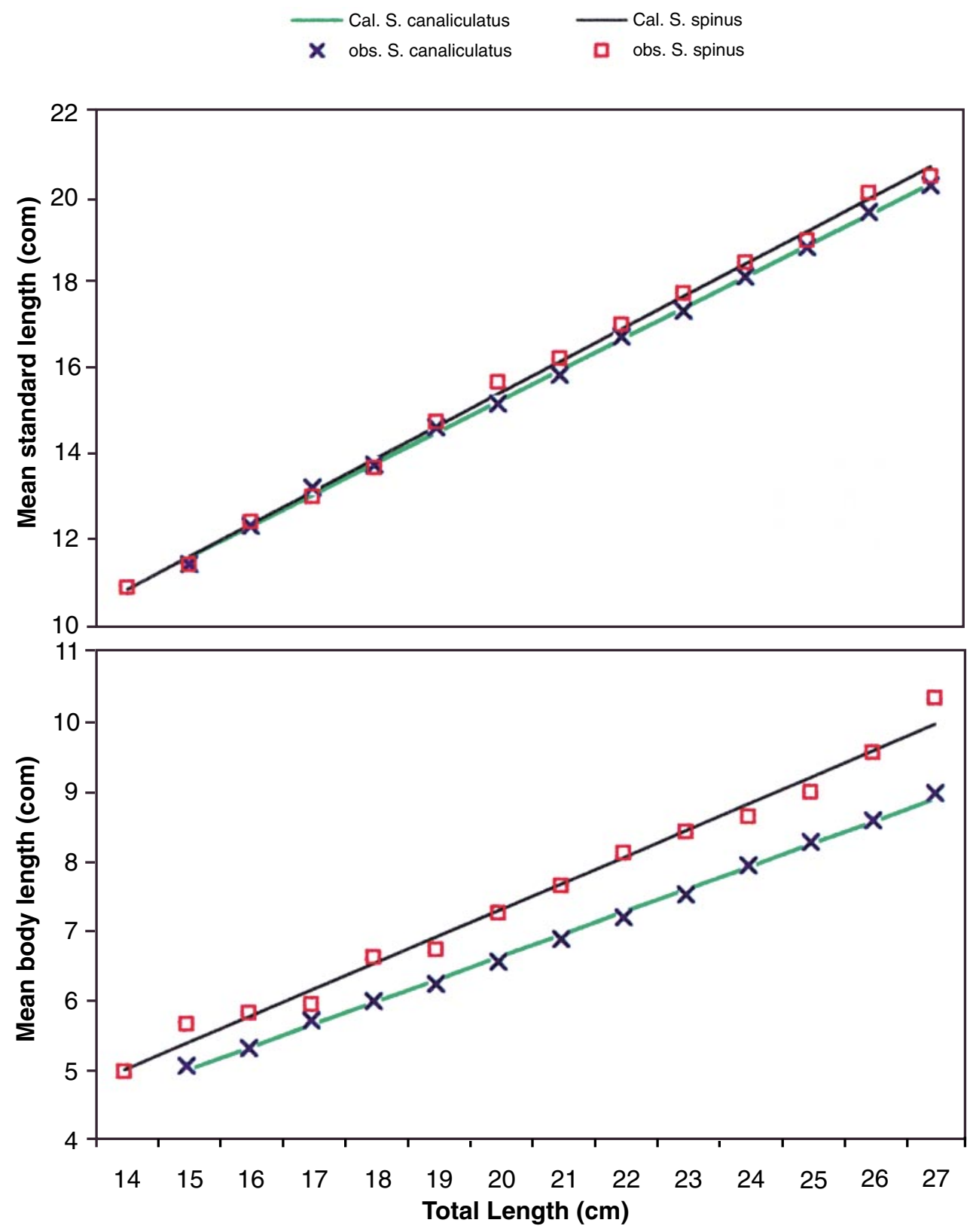

FIG. 2. Variations of standard length and body depth for S. canaliculatus and S. spinus (sexes combined).

The close agreement between the observed and calculated values (Fig. 2) proved the fitness of the derived equations, to describe two important diagnostic characters for the two species under study.

\section{Condition Factor (K)}

For all length groups, average $K$ varied between 0.96-1.32 (mean 1.18) for males and 0.98-1.49 (mean 1.2) for females $S$. canaliculatus. Sex varia- 
tions were tested not significant $(\mathrm{P}<0.05)$, and a mean condition factor of 1.2 was calculated for combined sexes. Figure (3) shows a marked decrease in $K$ values by increasing the length. Also it is evident that the highest value of $K(1.33)$ at length interval 14-19 cm TL. Figure (4a) clarifies that $K$ values began to increase from February to reach a maximum value (1.6) at April then decreased from May to July (spawning season) particularly for females. Examination of the $K$ seasonally (Fig. 4b) revealed a marked increase in spring (prespawning).

\section{Gonadal Development of S. canaliculatus}

S. canaliculatus was found to have unequal gonad lobes, where the left lobe (ovary or testis) becomes bigger in size throughout maturation cycle than the right lobe.

\section{Ovary (Fig. 6-11)}

The ovary wall, (tunica albuginea), consists typically of two muscle layers: The outer is of longitudinal muscle fibers, while the inner is of circular muscle fibers (Figs. 6a\&b). Ovigorous lamellae,

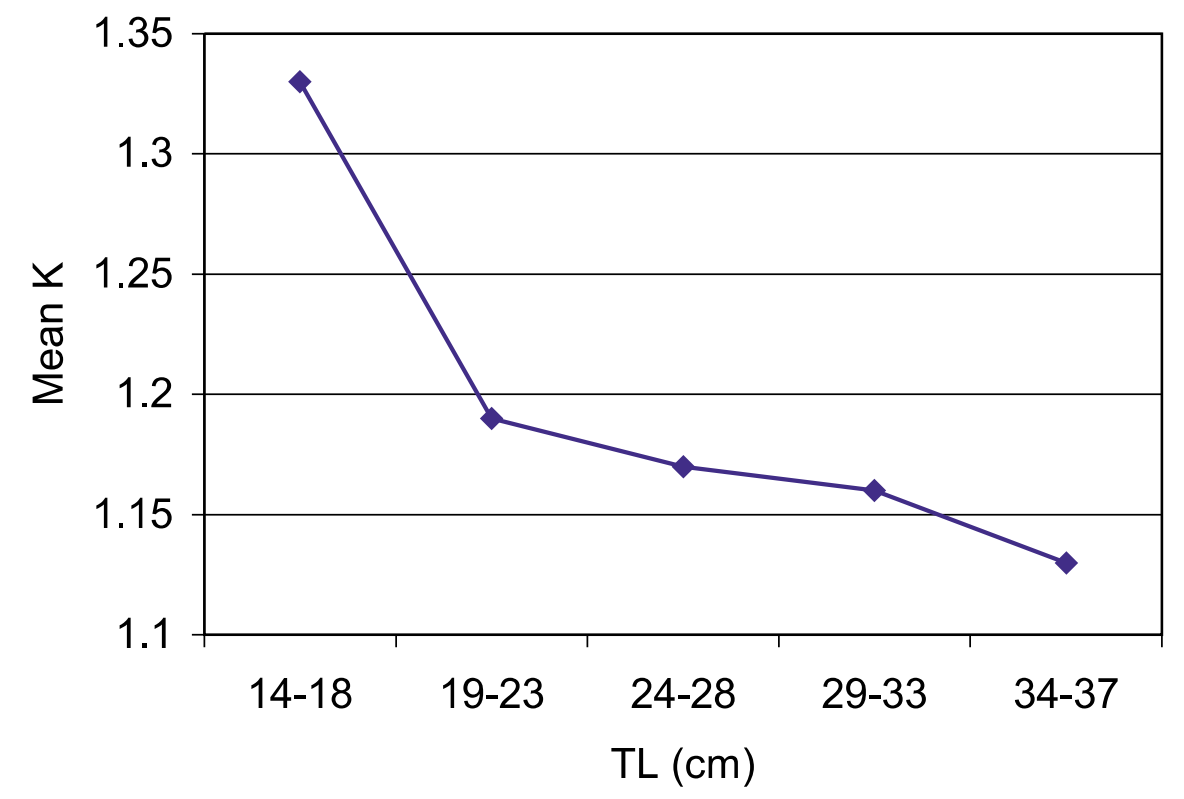

FIG. 3. Variations of mean condition factor (K) with total fish length (TL) for S. canaliculatus.

Weight/length relationship of $S$. canaliculatus. Using the grouped length $(L, \mathrm{~cm})$ and the corresponding total weights $(W, \mathrm{~g})$ of fishes ranging in total length from $15-36 \mathrm{~cm}$, the following equations were derived :

$\log W_{m}=-1.4564+2.7242 \log L_{m}(\mathrm{n}=1056$, $r=0.9984)$ (for males)

$\log W_{f}=-1.5072+2.7751 \log L_{f}(\mathrm{n}=967, r$ $=0.9982$ ) (for females)

Sex differences were tested (ANOVA) to be insignificant $(\mathrm{P}<0.05)$ accordingly, data were pooled and one equation was given to represent this relationship (Fig. 5) :

$\log W_{m f}=-1.4647+2.7352 \log L_{m f}(\mathrm{n}=2024$, $r=0.9979$ ) (for females) containing oogonia and oocytes, project from the tunica albuginea towards the center of the ovary (Fig. 6a). During the development of oocytes from oogonia, various transitional stages are identified therefore, a sub-stages are also given. Six major maturity stages are described as follows :

\section{Stage I, Rest or Chromatin Nucleolar Stage}

The rest stage of ovary (Fig. 6) extends from September to December (Av. GSI, 0.42). Oogonia, visible between the resting oocytes, were almost spherical in shape and are mostly found on the periphery of the lamellae. Nucleus is round, large and contain a single nucleolus associated with chromatin threads. The cytoplasm is thin and stains uniformly with no defined cell membrane. Chromatinnucleolar oocytes, are larger (av. diameter about 25 


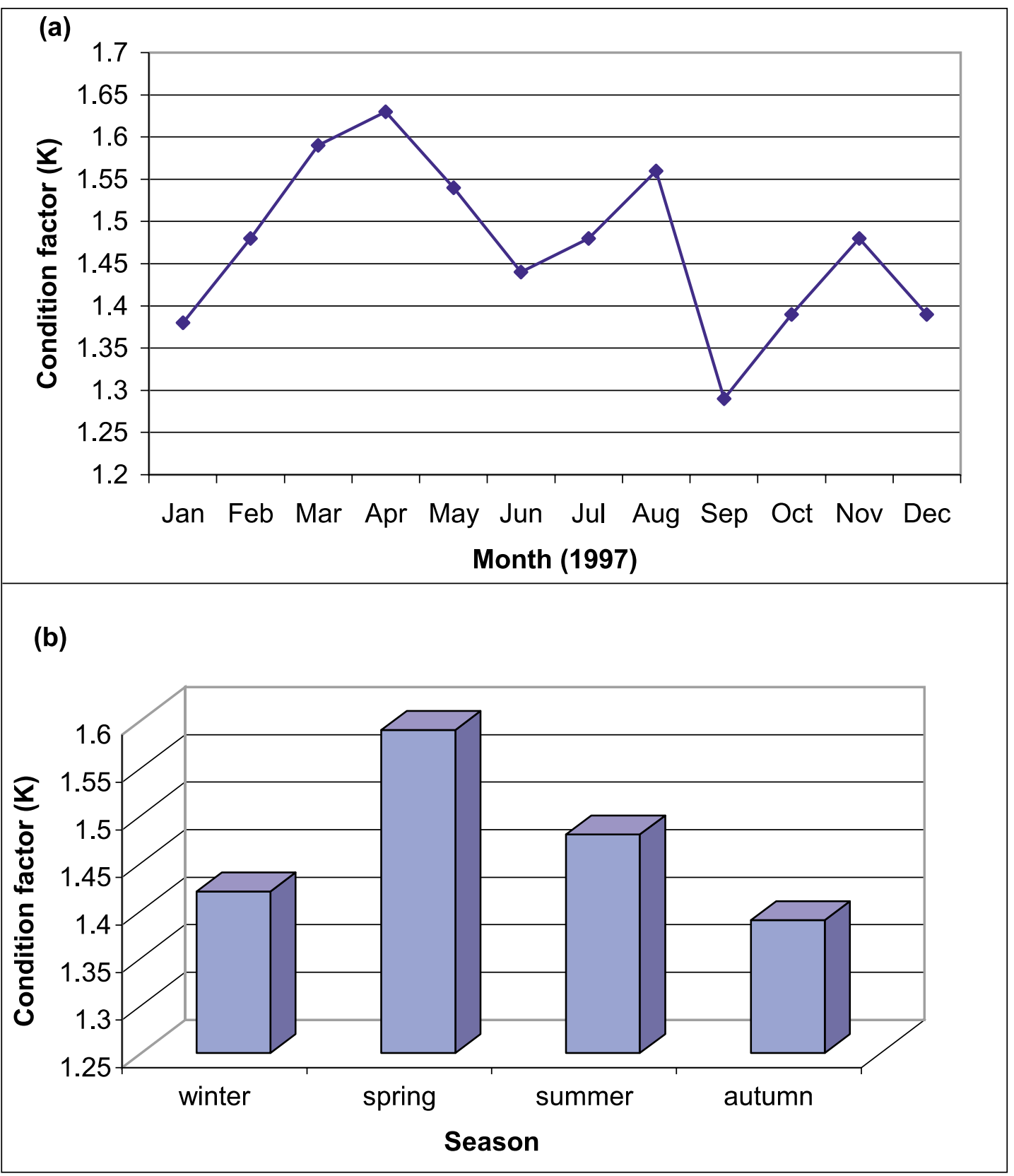

FIG. 4. Monthly (a) and seasonal (b) variations of condition factor (K) for sexes combined S. canaliculatus. 


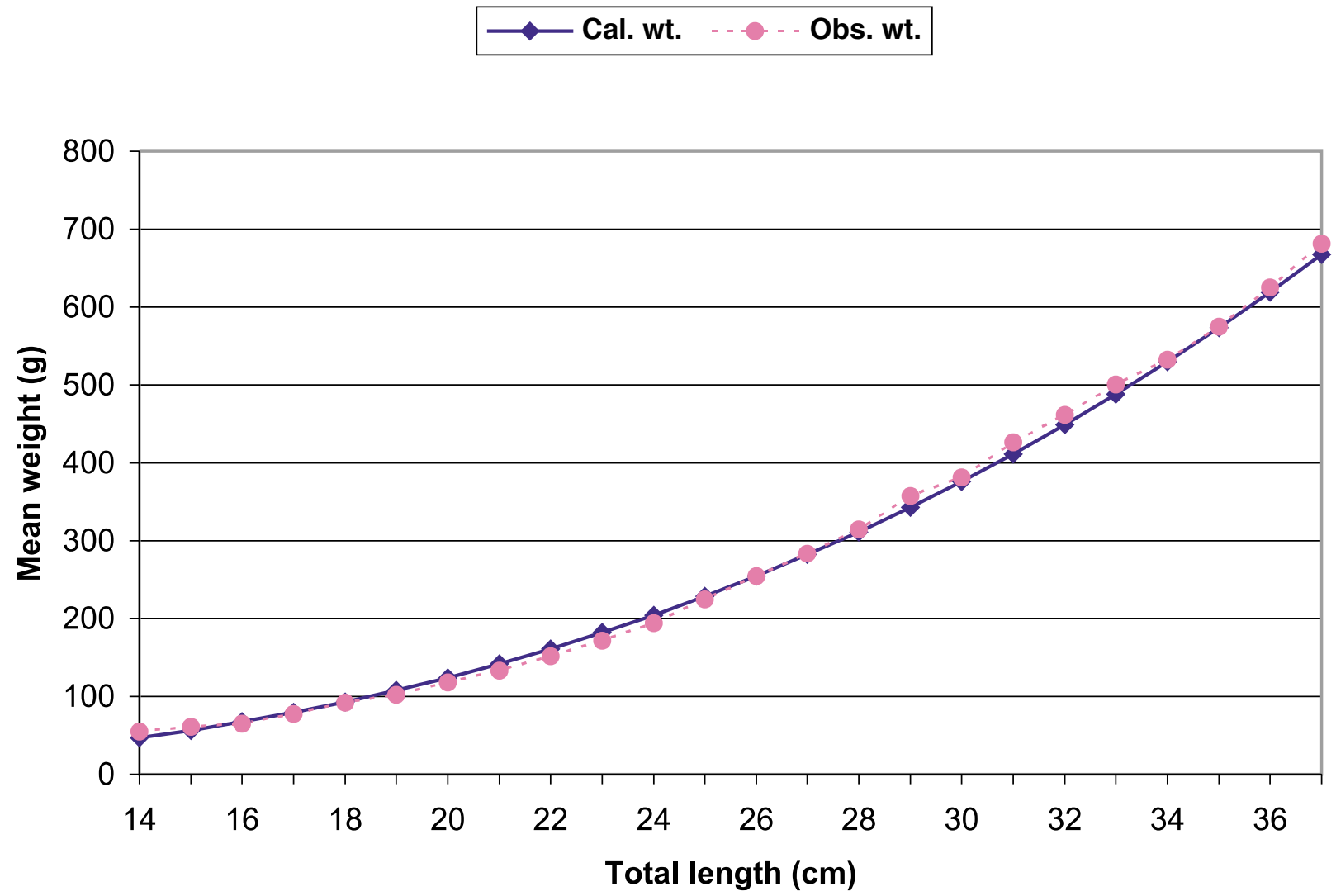

FIG. 5. Weight/length relationship for sexes combined S. canaliculatus.

$\mu \mathrm{m})$ than oogonia (Fig. 7a) and characterized by a well-defined dark ring of chromatin on the periphery of the nucleus. The nucleolus is very conspicuous and chromosomes are highly compact together forming a dark mass (Fig. 7b). Ovary wall (about $350 \mu \mathrm{m}$ thick).

\section{Stage II, Early Maturation (Perinucleolar Stage or Early Protoplasmic Growth)}

Perinuclear oocytes are irregular in shape, with no defined cell membrane, cytoplasm is homogenous and densely stained. These oocytes are divided into early perinuclear (av. diameter $35 \mu \mathrm{m}$ ) or late perinuclear oocytes (av. diameter $65 \mu \mathrm{m}$ ). Nucleus of the former is relatively large, centrally positioned and contains multiple small nucleoli (720) of various sizes. The later characterized by a granular cytoplasm appearance, sometimes differentiate to two zones, and two quite larger nucleoli (Fig. 7b).

\section{Stage III, Developing Stage (Yolk Vesicle Stage or Trophoplasmic Growth)}

Wide range of yolk vesicles deposition are formed in the ooplasm. Three phases (substages) are identified:

a) Primary yolk vesicle oocytes, are more or less round in shape (av. diameter $130 \mu \mathrm{m}$ ) Yolk vesicles appeared as purple small spherules or vacuoles. The nucleus is spherical containing numerous nucleoli at peripheral position (Fig. 8a).

b) Secondary yolk vesicle oocytes, are greatly enlarged in size (av. diameter $190 \mu \mathrm{m}$ ) due to deposition and accumulation of yolk globule. Few lipid droplets also formed in the central part of the cell. Larger oocytes start forming a definite chorion. (Fig. 8a).

c) Tertiary yolk vesicle oocytes, (about $360 \mu \mathrm{m}$ ) yolk globules show further increase in size, forming yolk spheres which begin to coalesce, at cell periphery and proceeds centerwards, giving rise to yolk mass in later stages. Larger lipid vacuoles appeared in the central part of the cell. Zona radiata is clearly defined (Fig 8b \& 9a). 


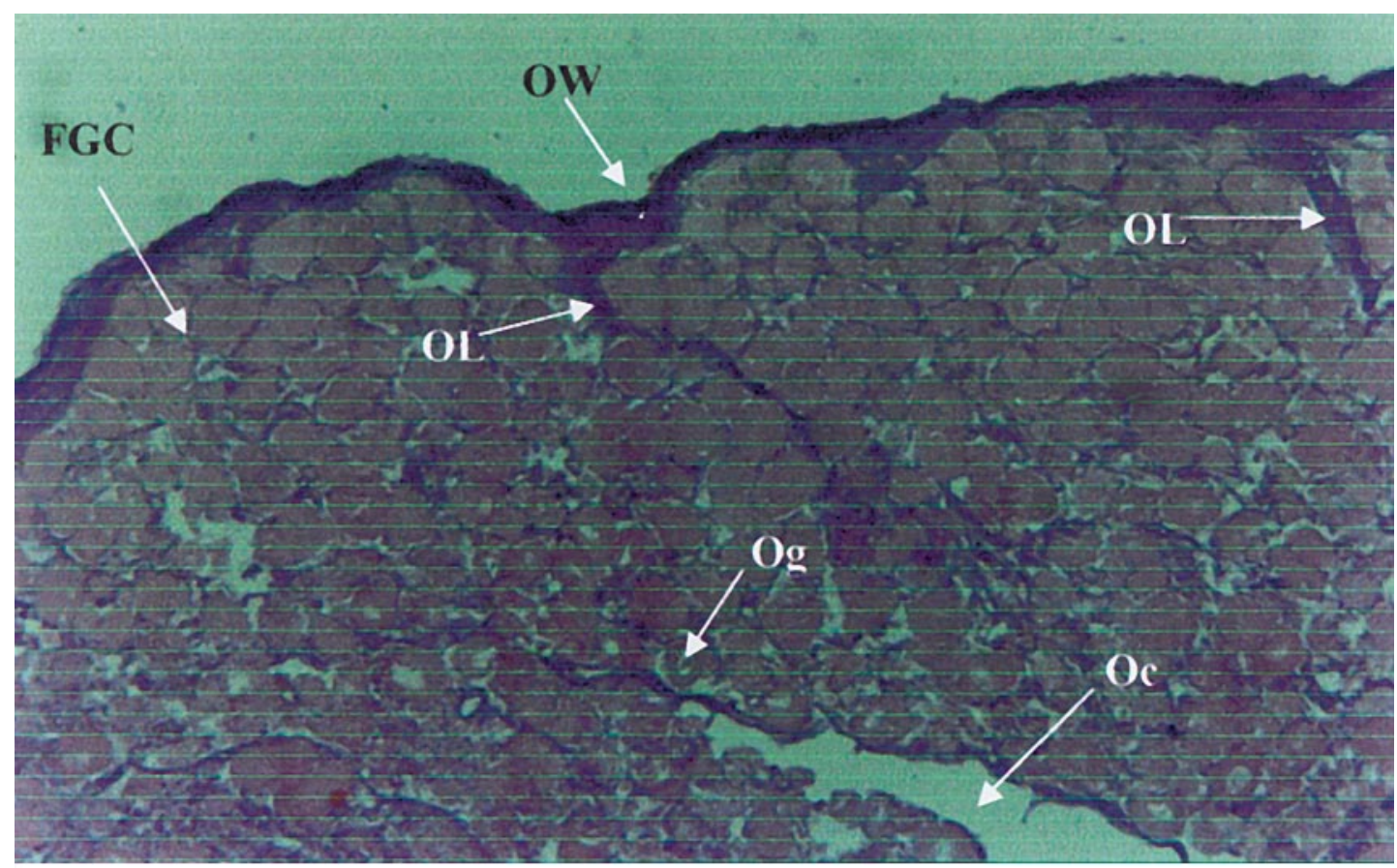

(a)



(b)

Fig. 6a. T.S in S. canaliculatus ovary $(19.5 \mathrm{~cm}$, December) $(40 \times)$ Rest stage: shows the ovary wall $(\mathrm{OW})$, oogonia $(\mathrm{Og})$ and ovocoel (Oc).

b. Highly magnified ovarian wall showing two muscle layers: an outer longitudinal (Lml) and inner circular $(\mathrm{Cml})(400 \times)$. 


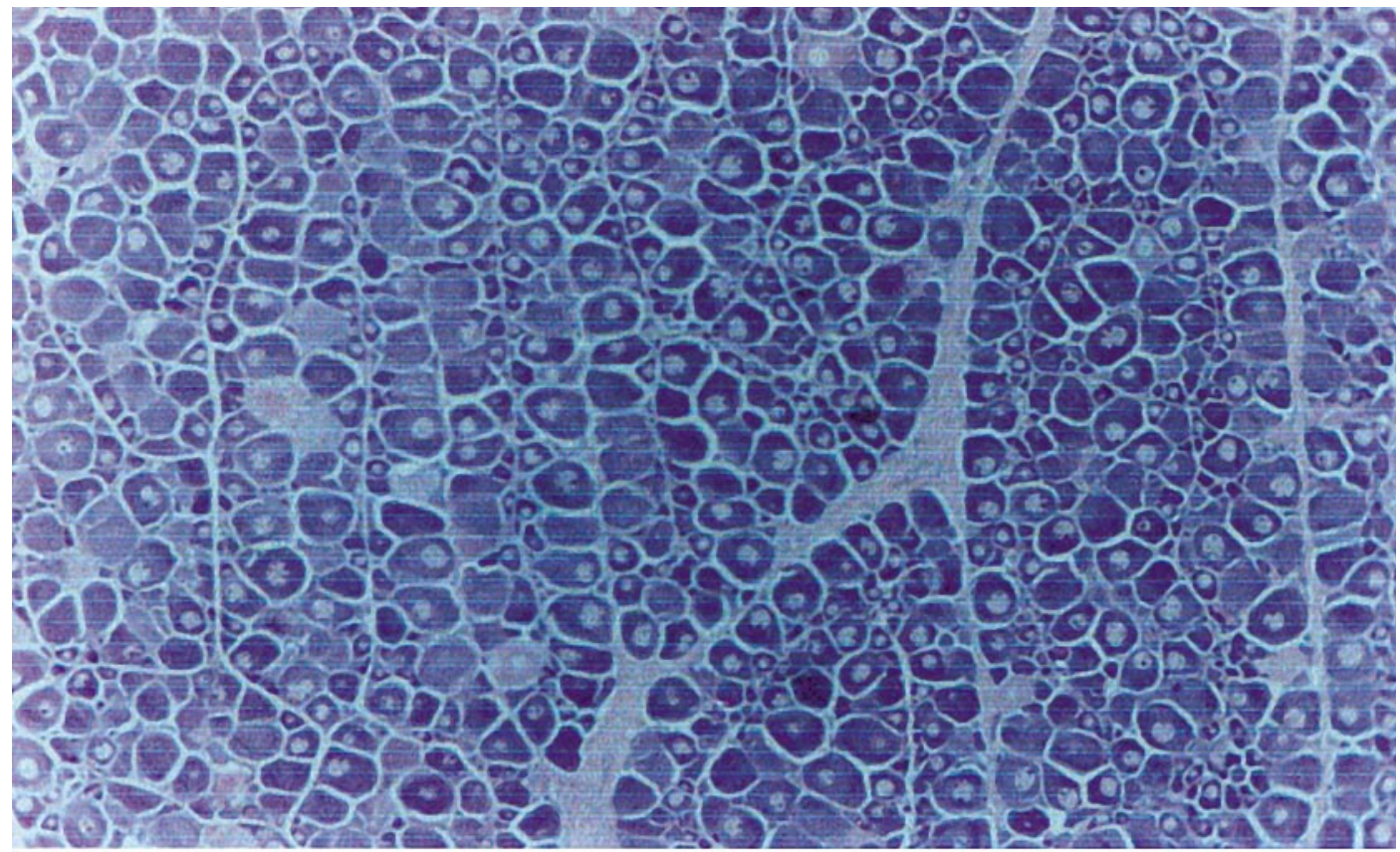

(a)

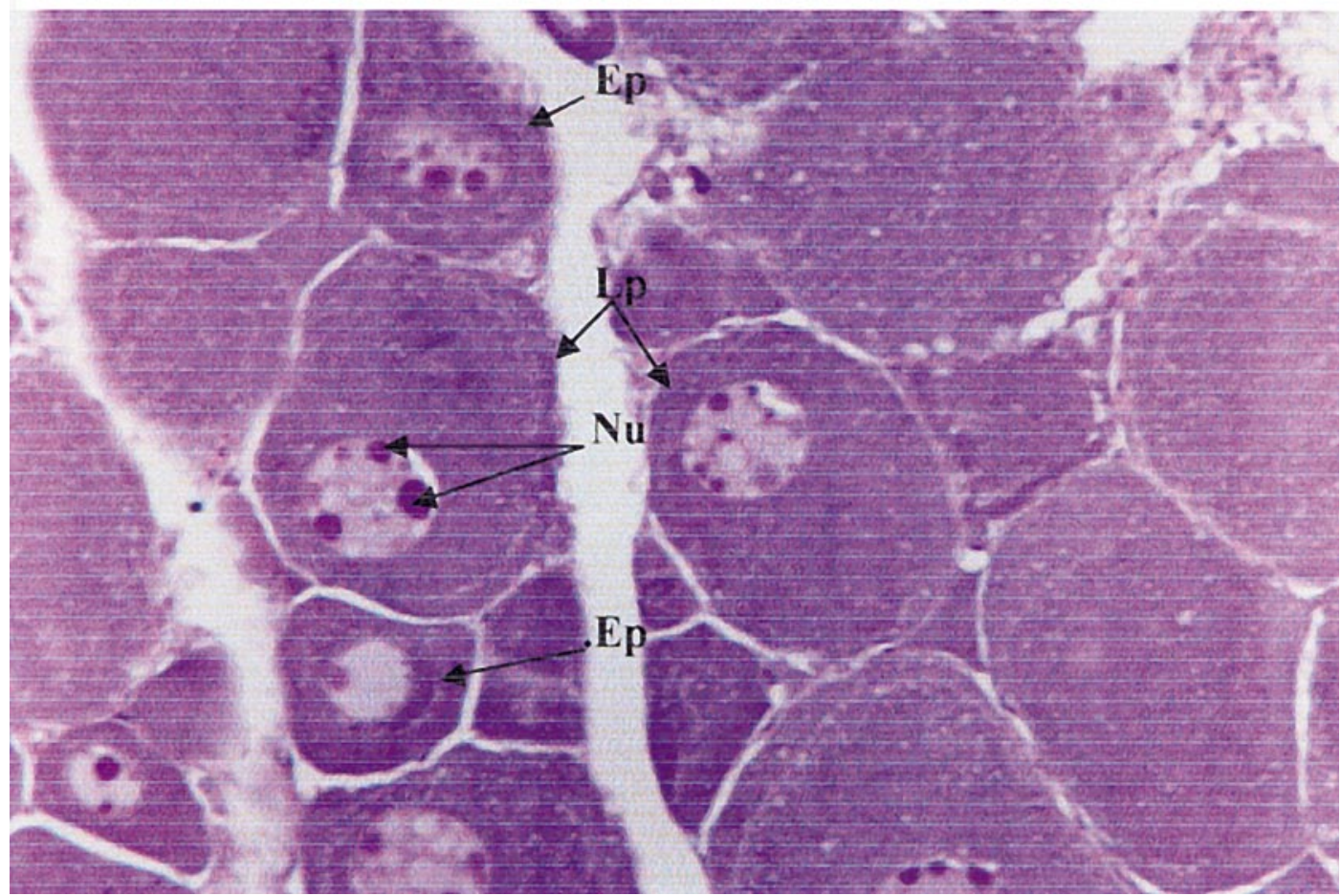

(b)

FIG. 7a. Early maturation stage ( $25 \mathrm{~cm}$, February GSI, 1.0) $(40 \times)$ : Shows oocytes at the early stages of growth.

b. Magnified early and late perinucleolar oocytes $(E p$ and $L p)(400 \times)$ Nu: Nucleoli, Yn: Yolk nucleus and Cz: cytoplasm zonation. 


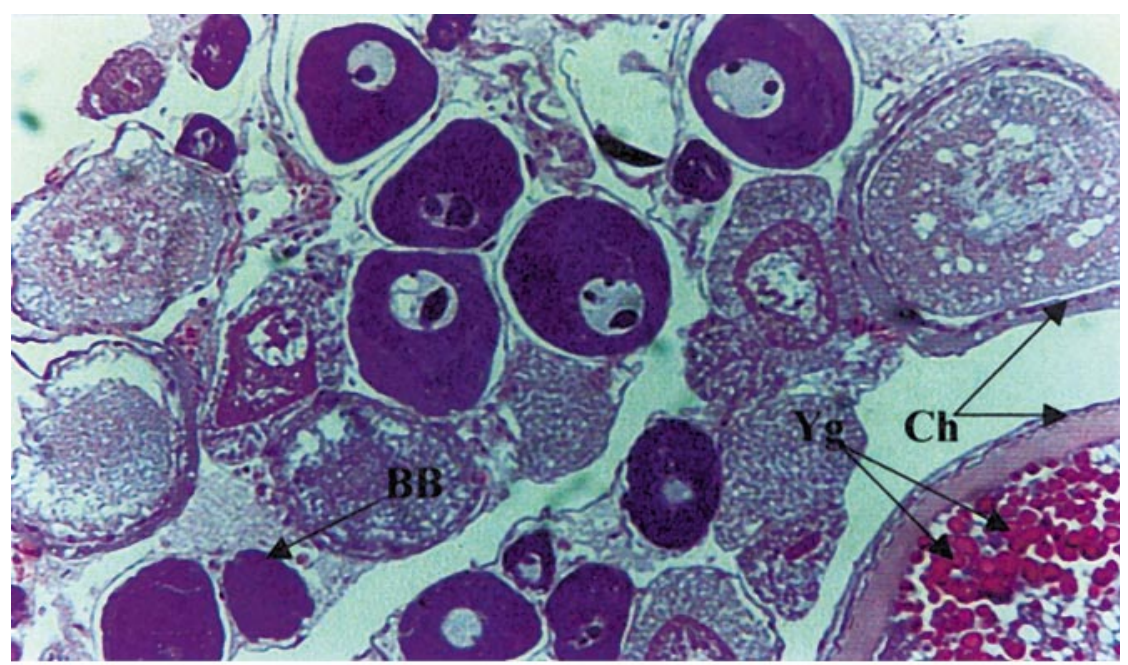

(a)

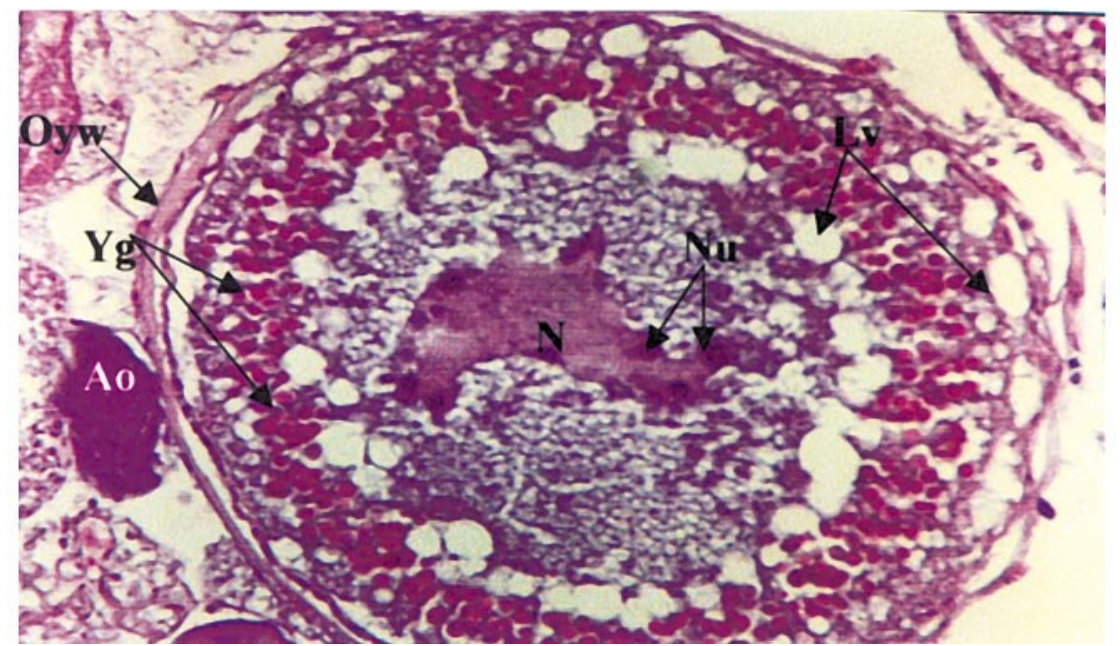

(b)

FIG. 8a. Developing stage (24 cm, March 10) (GSI 1.5) $(100 \times)$ shows the start of yolk deposition within the oocytes (early vitelogenic stage).

Pyo: Primary yolk vesicle oocyte, Yg: Yolk granules,

Syo: Secondary yolk vesicle oocyte, Ch: Chorion,

BB : Brown Body.

\section{Stage IV, Ripe/Prespawning Stage (Migratory Nucleus Oocytes)}

Yolk almost completely fills the oocyte, except for a very thin peripheral cytoplasmic layer. Nuclear membrane disappears and the nuclear matrix has shifted to the periphery of the cell (animal pole) (Fig. 9a). Most of the nucleoli retain their peripheral distribution, until they finally disappear. All lipid drops have fused and yolk liquefaction commences (Fig. 9b). Zona radiata layer, beneath the comparatively flat follicular cells, has clear radial striations. Ovarian wall thin $(80 \mu \mathrm{m})$. Ripe oocytes are almost the same size $(360-450 \mu \mathrm{m})$ (Fig. 10) and some oocytes exhibited atresia (Fig. 9).

\section{Stage V, Running Stage}

Some empty follicles appear (Fig. 10), indicating that spawning has started, and increase in number in later stages (Fig. 11).

\section{Stage VI, Spent Stage}

Definite empty follicular coats are majority with residual atretic oocytes. Larger oocytes $(170 \mu \mathrm{m})$ also exist Ovarian wall thickness about $300 \mu \mathrm{m}$. 


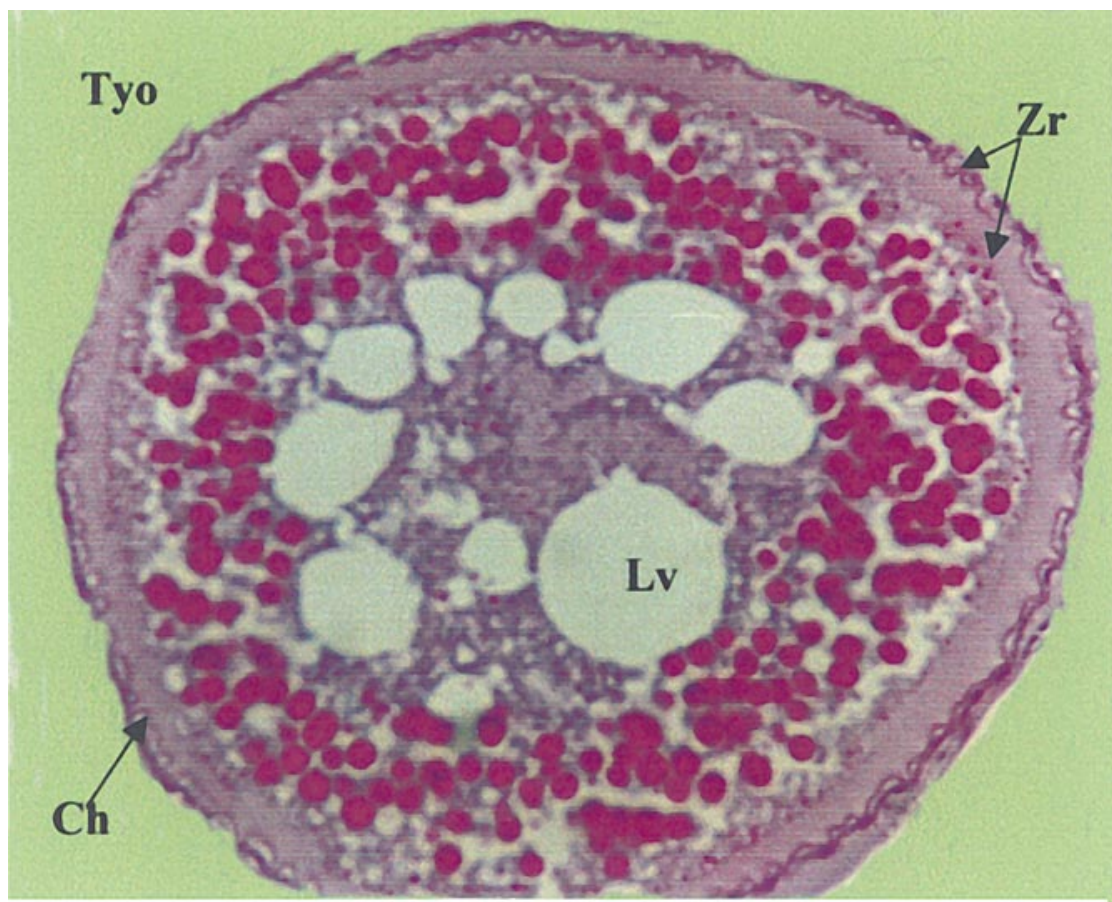

(a)

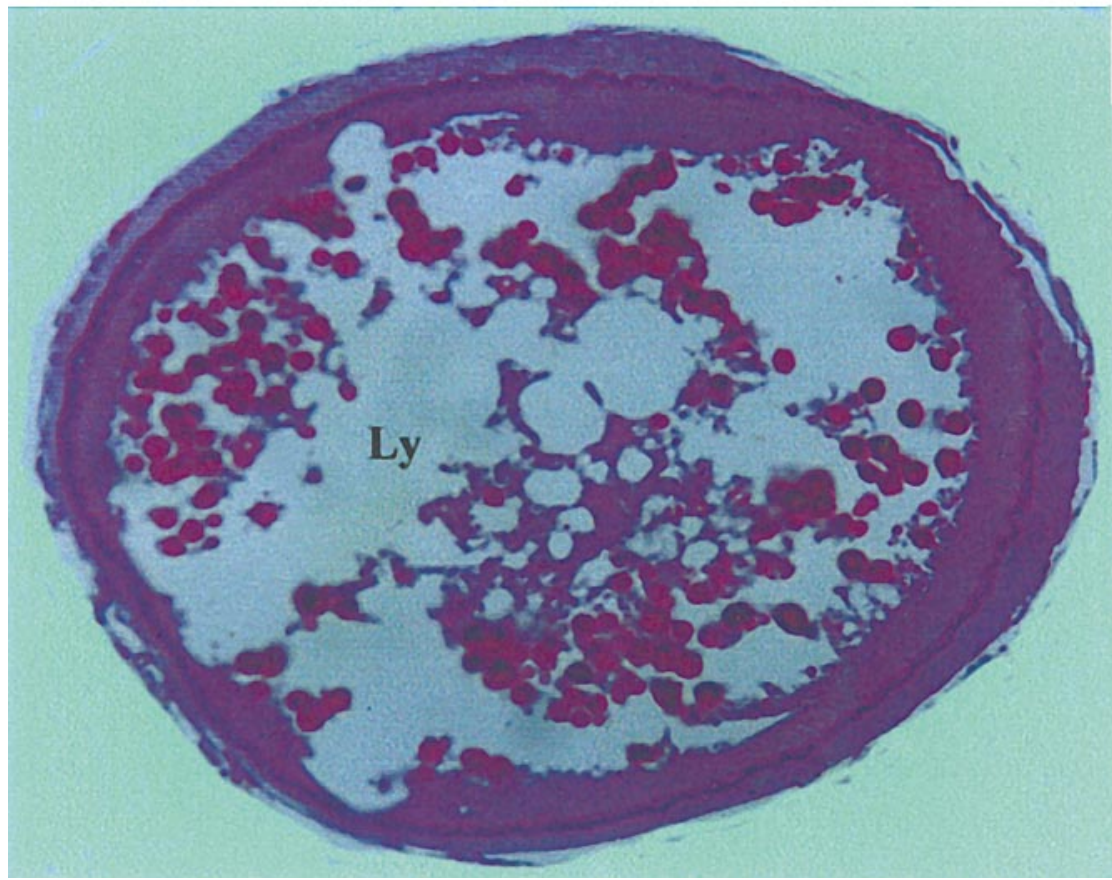

(b)

FIG. 9a. Ripe stage (32 cm, April 10) $(400 \times)$. A magnified tertiary yolk vesicle oocyte (Tyo) (ripe oocyte). A magnified tertiary yolk vesicle oocyte (Tyo) (ripe oocyte).

Lv: Lipid vacuoles, Ch: Chorion and Zr: Zona radiata.

b. Ripe ovum showed yolk liquefaction (GSI 12) $(400 \times)$ Ly liquid yolk. 


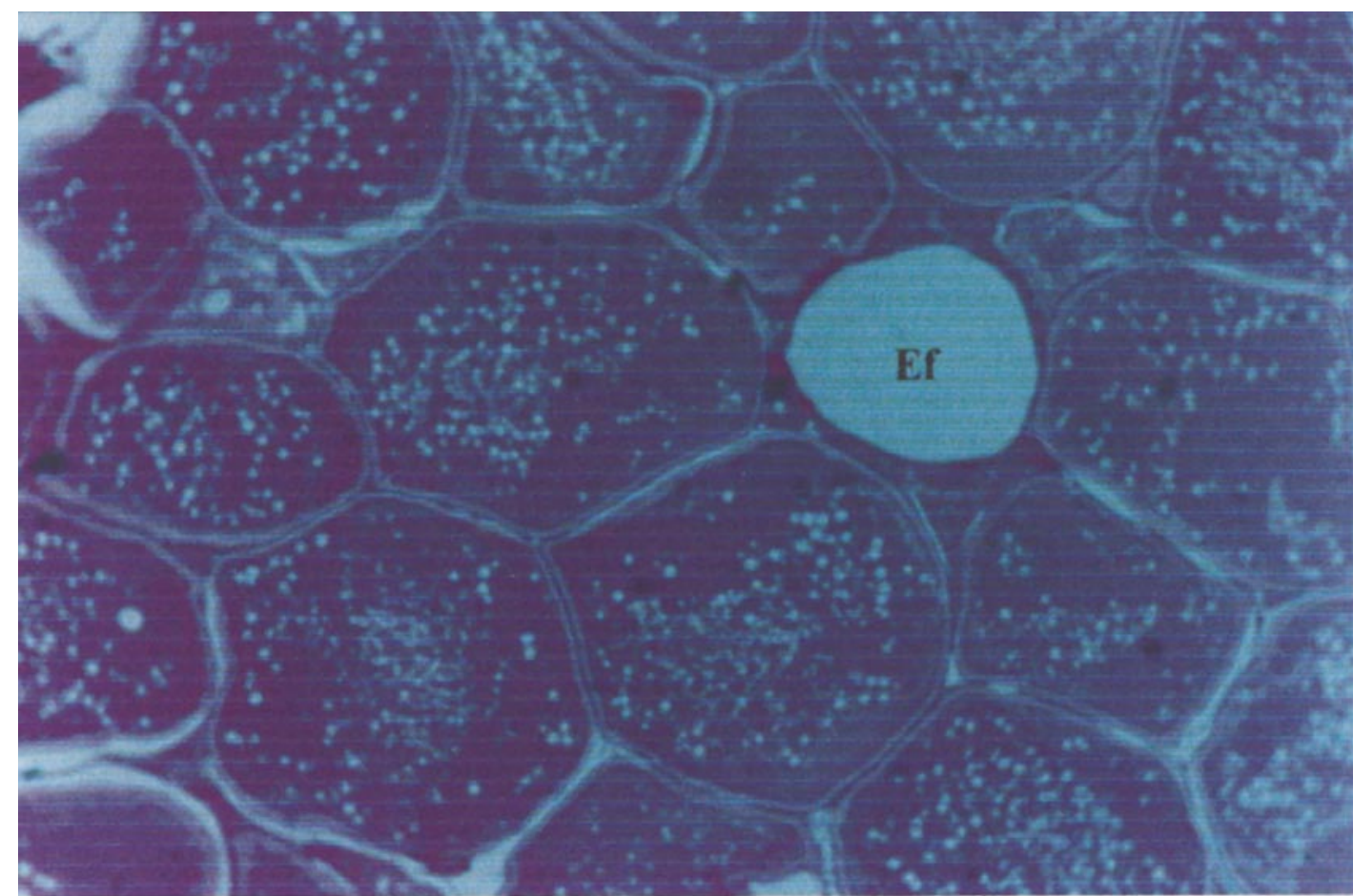

(a)

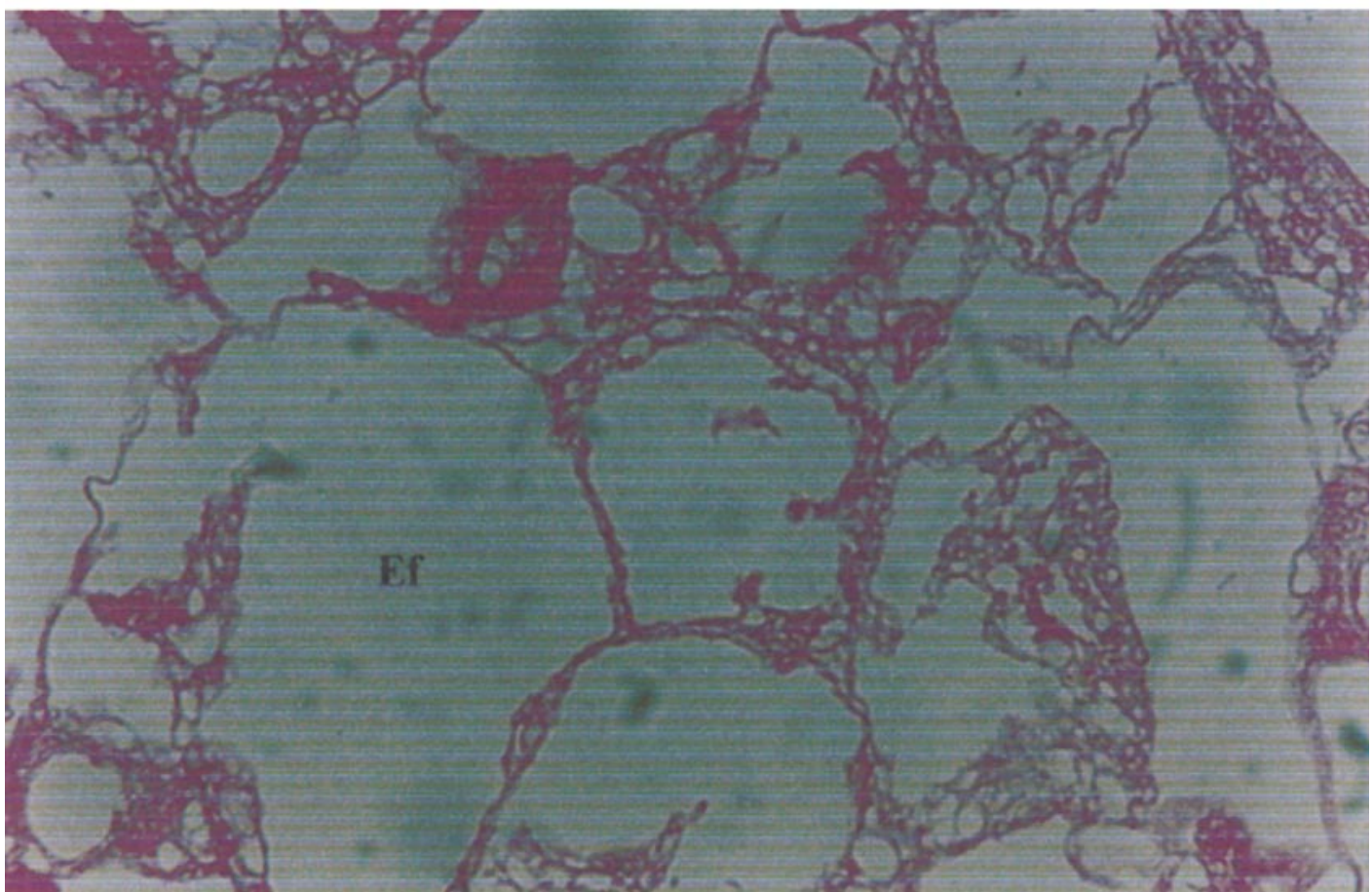

(b)

FIG. 10. Running stage $(26 \mathrm{~cm}$, May 10) (GSI 10) $(100 \times)$ showing the ripe ova at different liquefaction stages and first appearance of empty follicle (EF). 


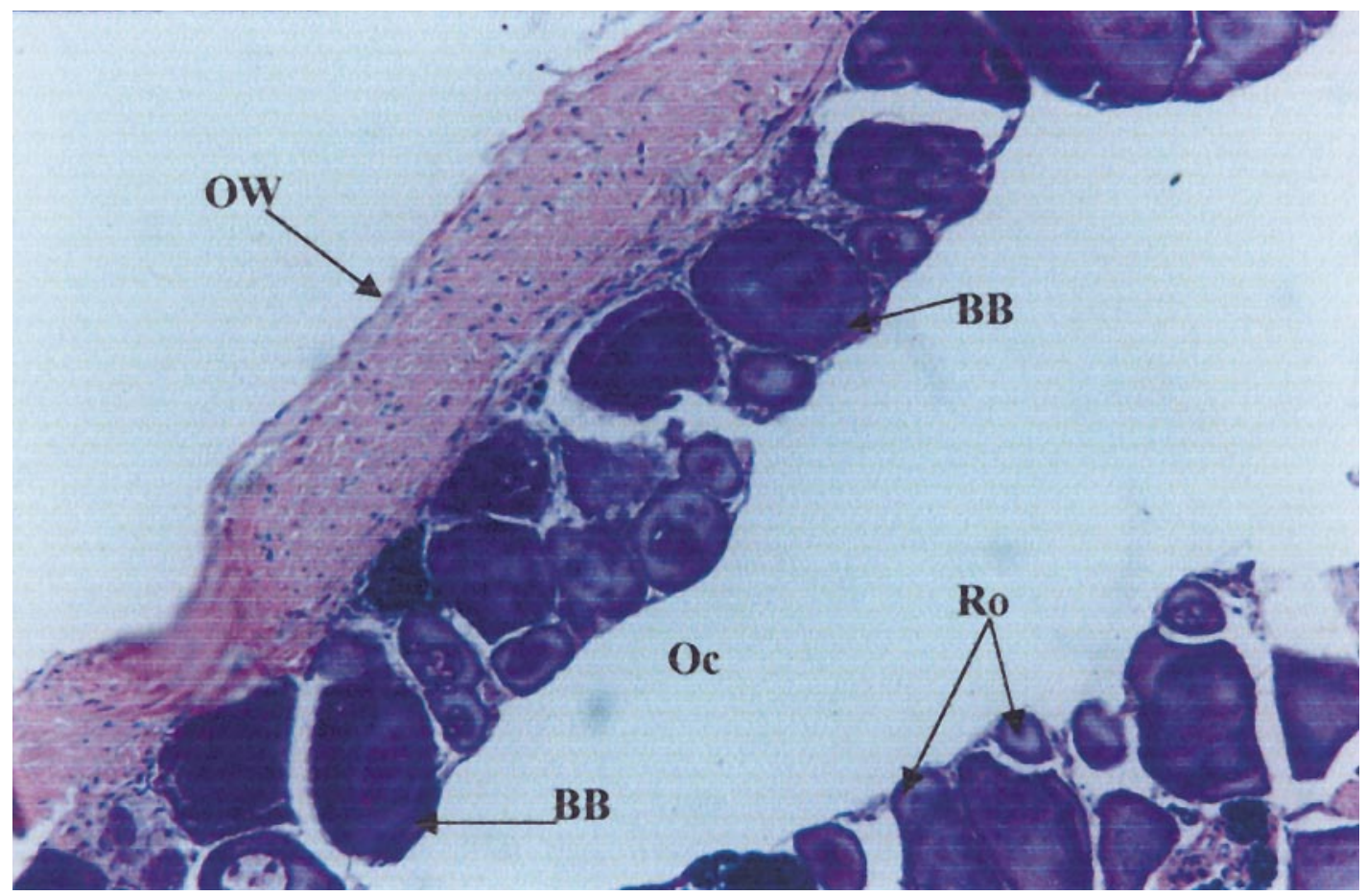

FIG. 11. Spent stage (29 cm, May 30) (GSI 2.02) $(100 \times)$. Completely spent ovary showing empty follicles (EF).

\section{Testis (Fig. 12-17)}

As in the majority of teleosts, testis of S. canaliculatus is of the lobular type, seems multi-lobed in ripe condition. In sections, the testis is composed of numerous semineferous lobules arranged in a radial way and separated by fibrous connective tissue (Fig. 12a). The lobular wall containing cysts, the primary male germ cells are large (av. diameter $10 \mu \mathrm{m}$ ), lightly stained with a large nucleus (Fig. 12b). Testicular wall (tunica propria, about $100 \mu \mathrm{m}$ thick).

Spermatogenesis takes place within these lobules and mature sperms are released into the collecting ducts at the end of the maturation cycle. The changes in the germ cells associated with sperm development are shown in Fig. 12 -17.

Spermatogonia, have pale cytoplasm and a small central nucleus (av. diameter $7.5 \mu \mathrm{m}$ ), often occur as groups attached to lobulel's wall. They found at most stages of testis maturation. Primary spermatocytes are smaller in size (av. diameter about 3.5 $\mu \mathrm{m}$ ), darker in color, cell wall is unrecognizable and nucleus is small. Groups of secondary spermatocytes, are identifiable by their relatively smaller size, homogenously staining nuclei and their patches appear darker within the sperm cyst (Fig. 13b). Spermatids, have very small, intensely-staining nuclei occupying most of the cell, therefore appear the smallest (av. diameter $1.5 \mu \mathrm{m}$ ) as well as darkest cells at later stages (Fig. 14). Spermiogenesis, which occur in lobules lumen, is evidenced by the appearance of free spermatozoa which are clearly identifiable by their tails. In the ripe stages, the predominance of Parashut-like sperm clumps within the lobules are recognizable (Fig. 15). Lobular wall undetectable. Tunica become thin and enlarged. In running males the lobules are filled with milt (Fig. 16) which facilitate the release of sperm patches during the spawning season. In spent stage, empty lobules are majority with thick interstatial tissues (Fig. 17a). By the end of spawning cycle, only spermatogonia and residual spermatozoa are present within the lobules (Fig. 17b).

\section{Discussion}

Rabbitfishes belonging to the family Siganidae include a group of potentially important aquaculture species occurring in the Indo-Pacific, Indian Ocean, Red Sea and Eastern Mediterranean regions 


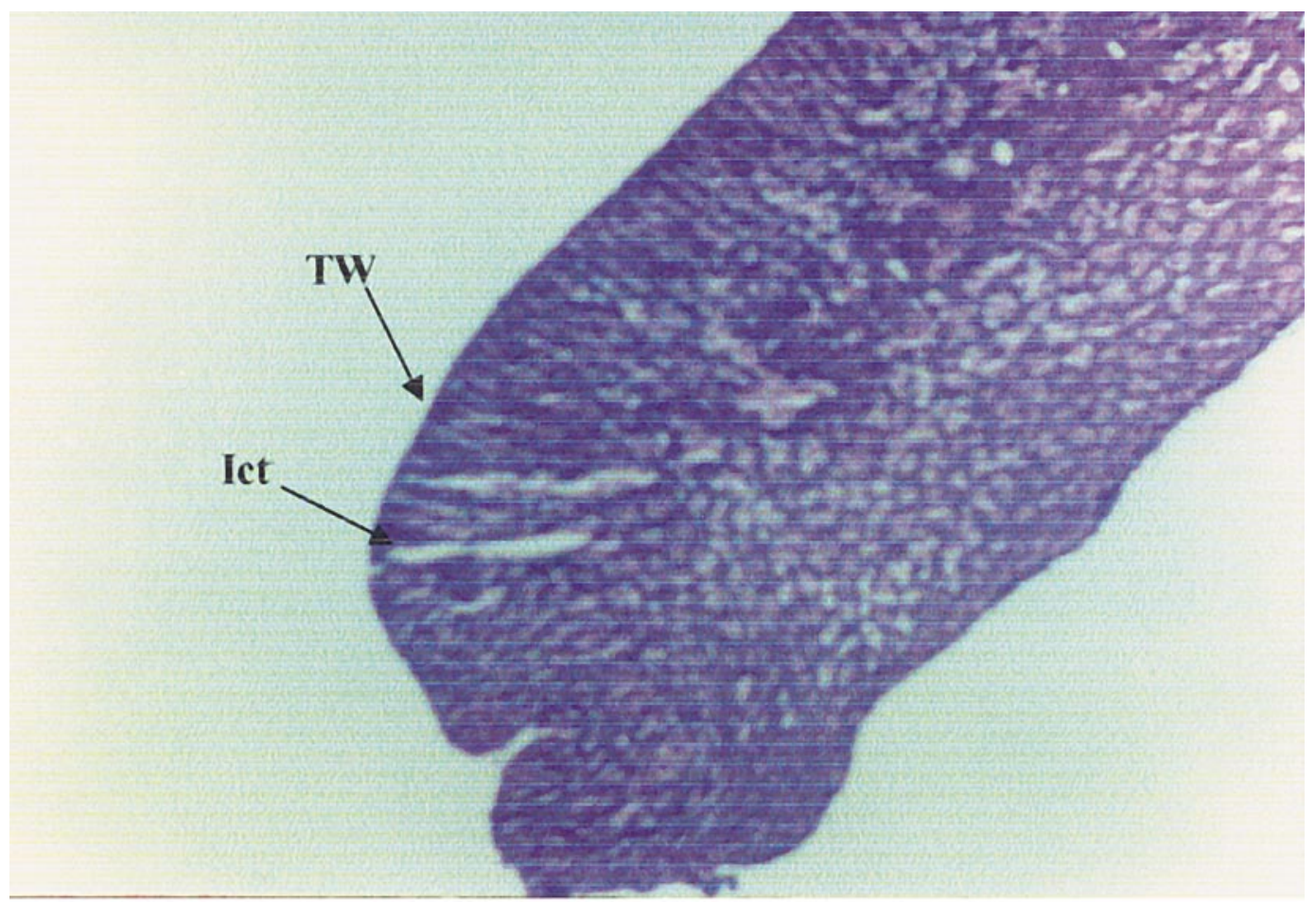

(a)

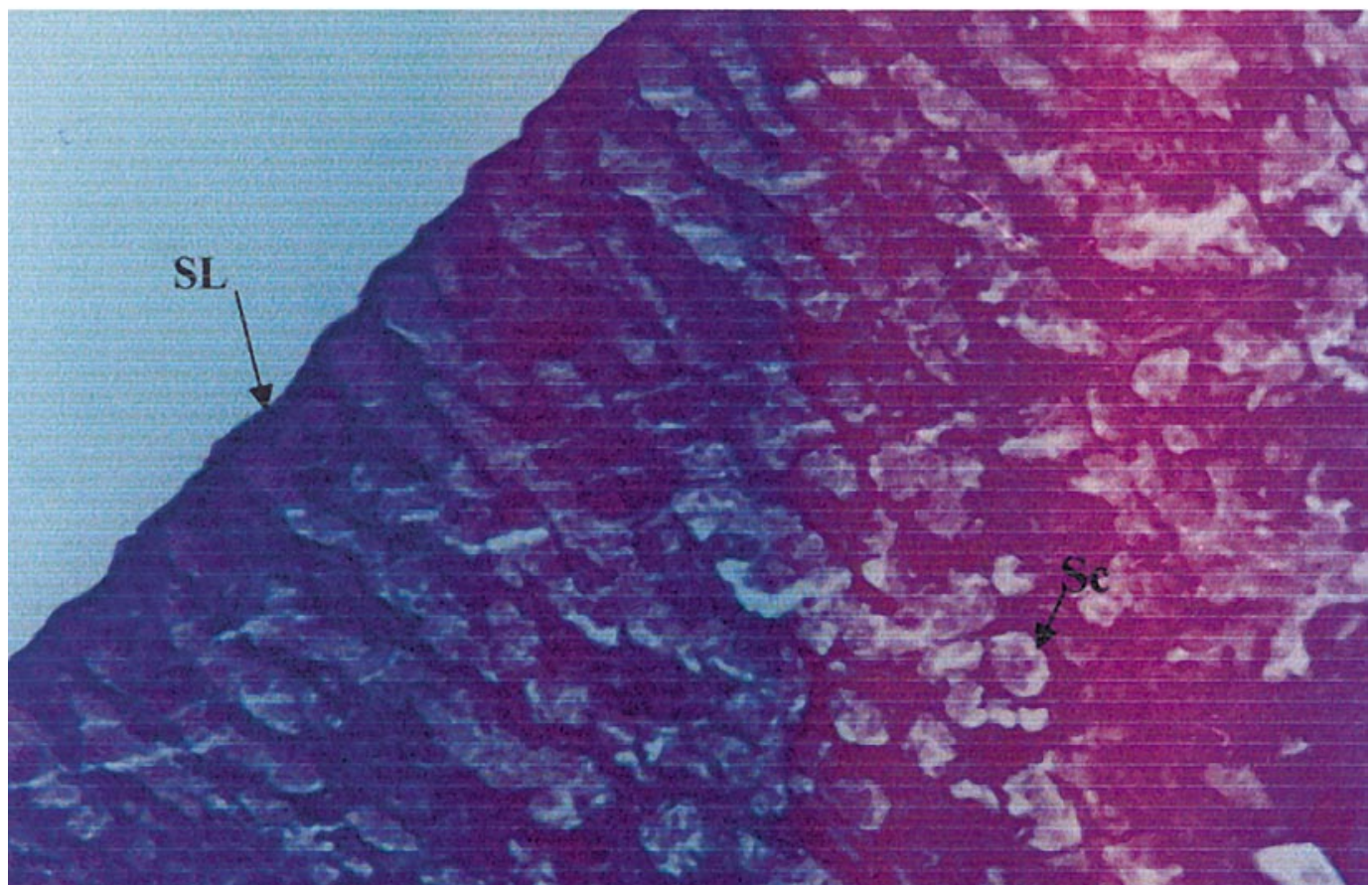

(b)

FIg. 12a. T.S. in testis $S$. canaliculatus $(16 \mathrm{~cm}$, December) (GSI 0.42) $(40 \times)$. Rest stage: Showing semineferous lobules (SL) arranged in a radial way.

TW: Testicular Wall, Ict: Interstitial connective tissue.

b. A magnified part from the previous section $(100 \times)$. Sc: Sperm cyst. 


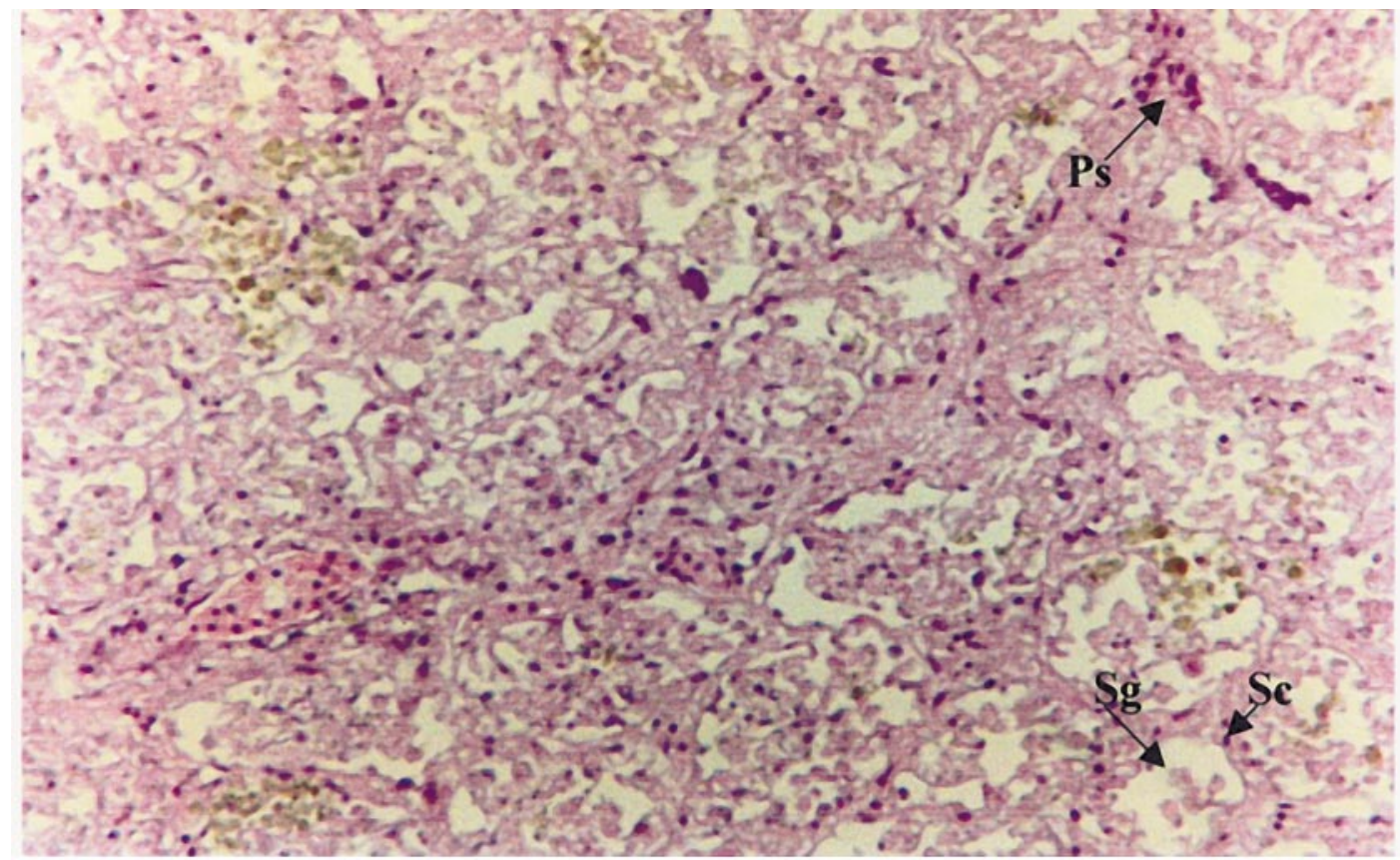

(a)

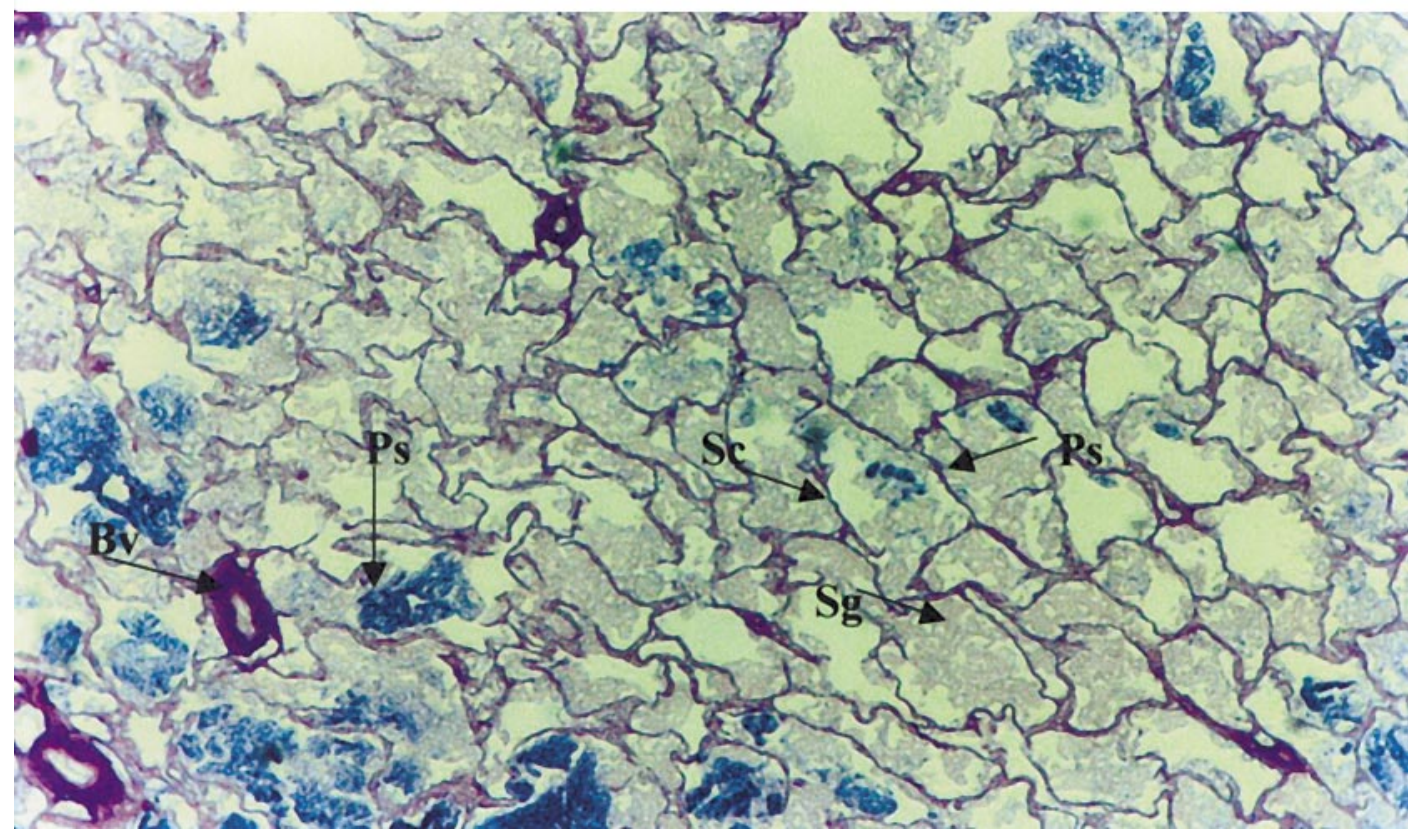

(b)

FIg. 13a. Advanced early maturation stage $(25 \mathrm{~cm}$, February) $(\mathrm{GSI} 0.68)(100 \times)$ shows sperm cysts $(\mathrm{Sc})$ filled with primary and secondary spermatocytes.

Sc: Sperm cysts, Sg: Spermatogonia

b. Advanced early maturation stage $(25 \mathrm{~cm}$, February) (GSI 0.68$)(100 \times)$ shows sperm cysts $(\mathrm{Sc})$ filled with primary and secondary spermatocytes.

Ps: Primary spermatocytes, Sc: Secondary spermatocytes, Bv: Blood vessels. 


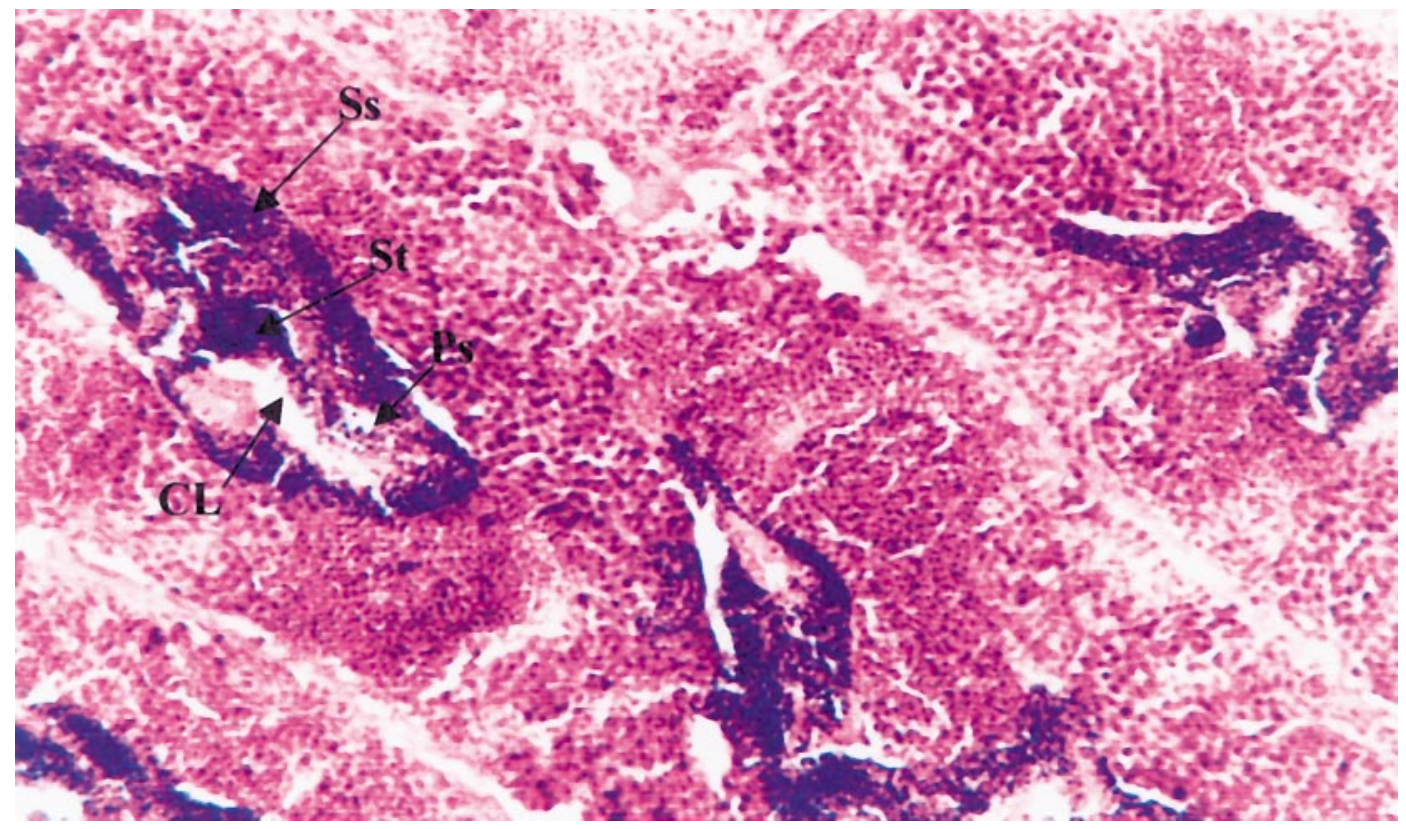

FIG. 14. Developing stage $(29 \mathrm{~cm}$, March) (GSI 1.37) $(100 \times)$, shows different growth phases of spermatocytes within the sperm cysts (Sc).

Ps : Primary spermatocytes, $\quad \mathrm{Cl}:$ Cyst lumen,

Sc: Secondary spermatocytes, St : Spermatids.

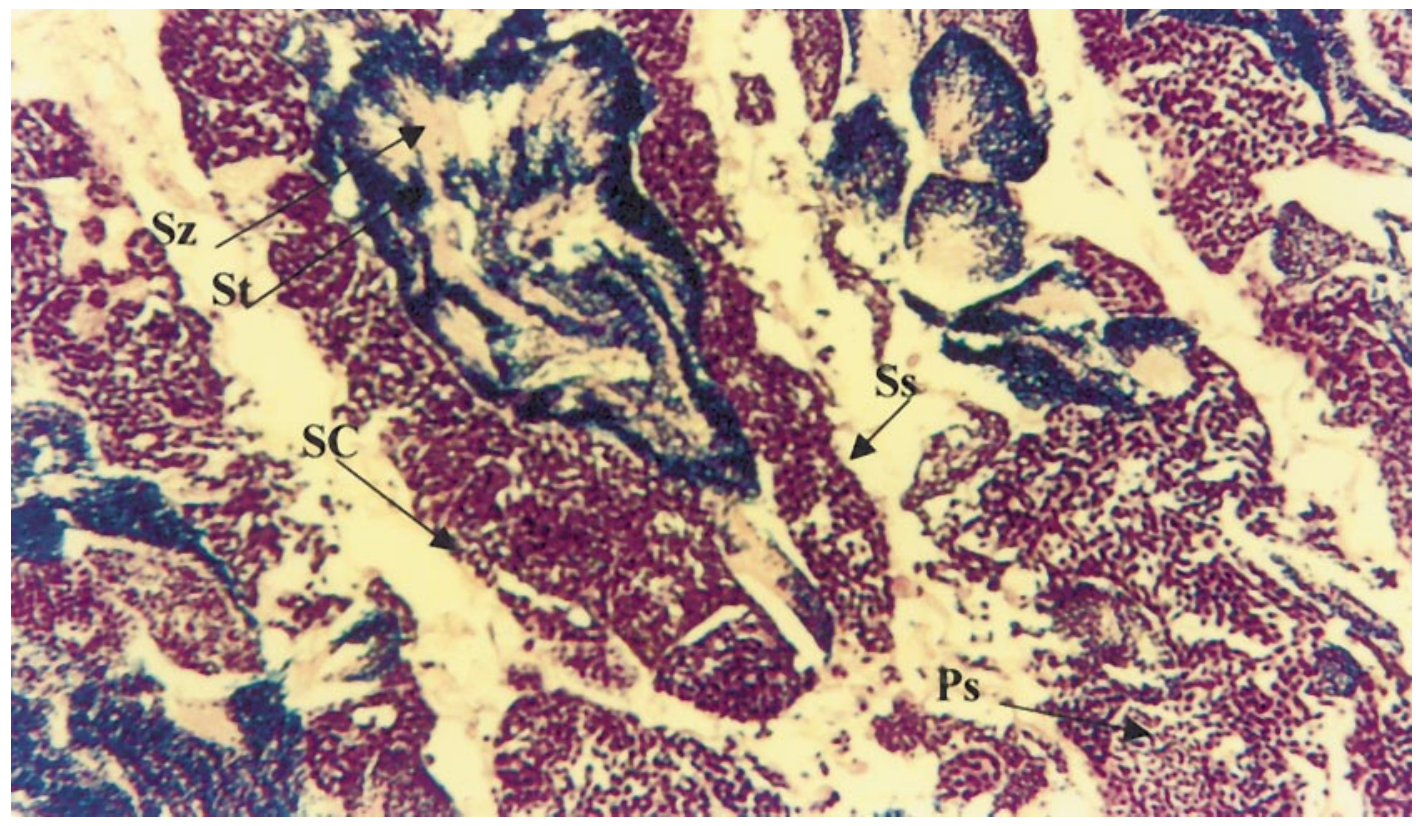

FIG. 15. Ripe stage (22 cm, April 10) (GSI 12) $(400 \times)$. Early sperminogenesis process showing parachute-like sperms or spermatozoa (Sz).

Sc: Sperm cyst, St: Spermatids, Ss: Spermatocytes. 


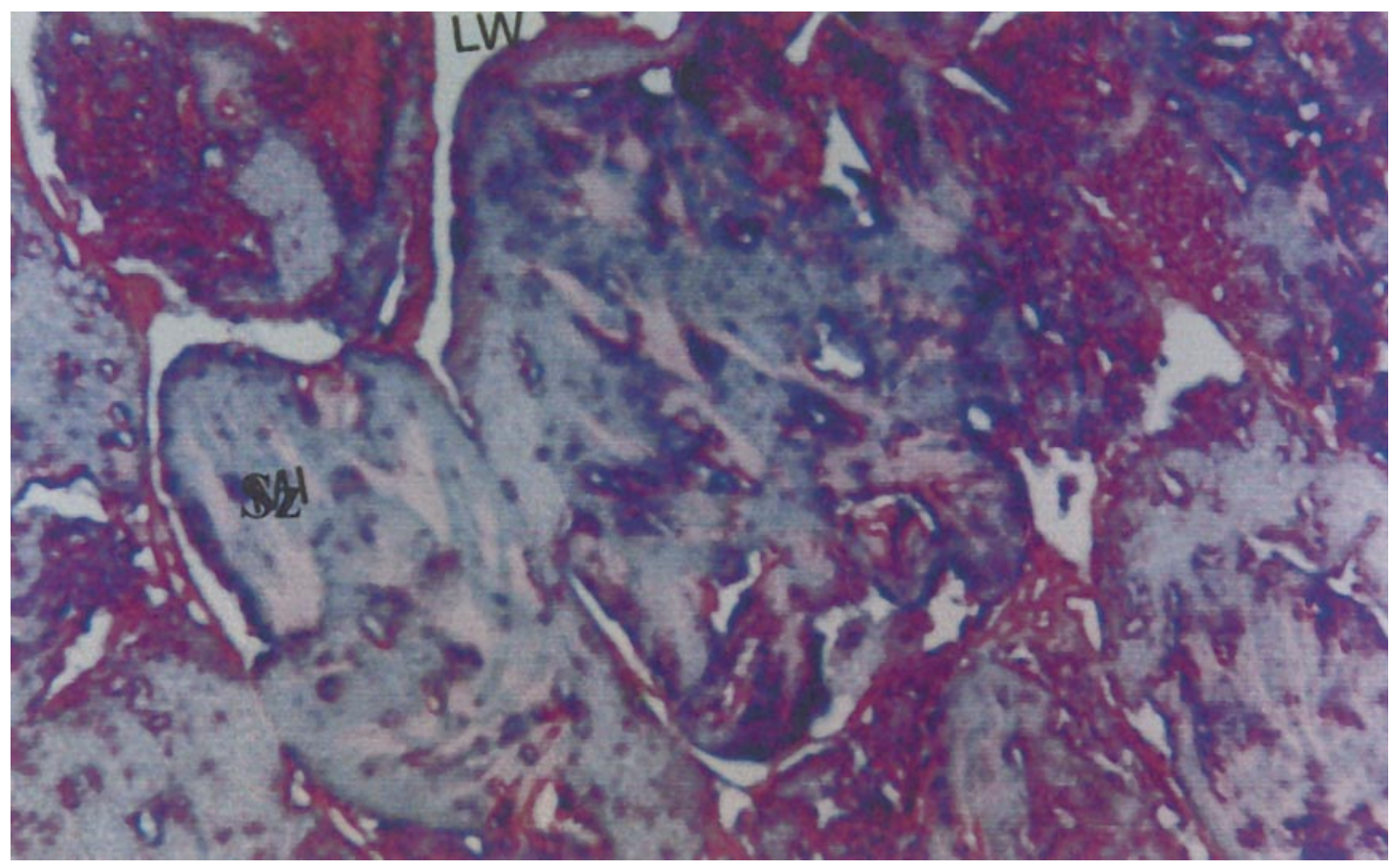

FIG. 16. Running stage (26 cm, April 20) (GSI 12) (400×). Lobules filled with Spermatozoa: Sz, LW: Lobular wall.

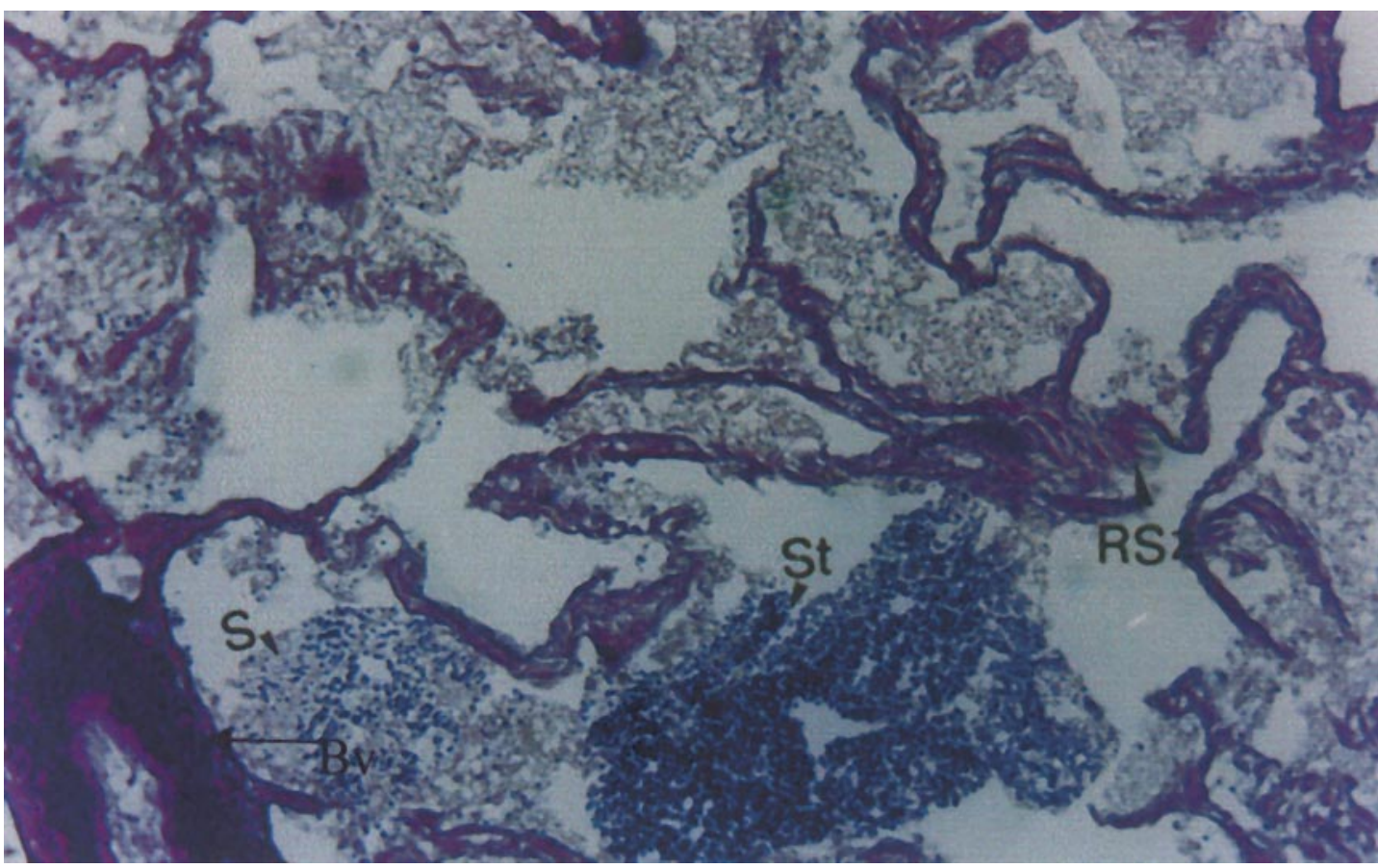

FIG. 17. Spent stage (partially spent): $(29 \mathrm{~cm}$, May 10) (GSI 4.57) $(100 \times)$, shows almost empty sperm lobules after the release of sperms.

Rs: Residual sperms, St: Spermatids, Bv: Blood vessel. 
(Woodland, 1983 and Pillay, 1990). They attracted the attention of aquaculturists because of their predominantly herbivorous feeding habits, fast growth rates and high prices in the markets. Earlier investigations on rabbitfish cultivation have shown that $S$. canaliculatus has good culture potential. The fish is euryhaline and grows well in captivity and in coastal areas (Lam, 1974, Al-Ardi et al., 1985, Bwathondi, 1986, Kungvankij et al., 1990, Tacon et al., 1989, Tawada, 1991 and Nelson et al., 1992).

Although many taxonomic studies were carried out, only few have dealt with the morphometry (Mohamed, 1991 \& Moharrum, 1994 for Siganus rivulatus and $S$. luridus). Knowledge about $S$. canaliculatus and $S$. spinus has been so far scarce. The present work evidenced that these species are not sexually dimorphic. The analysis of the morphometric parameters and indices proved uniformity of body depth of males and females fish and ascribes significant body growth differences between the two species under study in mid Arabian Gulf region. The derived morphometric indices are of particular importance as diagnostic features for each species and can also serve for any other taxonomic purposes. In earlier studies, sexual dimorphism in siganids was reported by Helfman (1968). Males are said to have slightly more elongated body than females of the same length. Also, Manacop (1937) wrote that that during the breeding season of $\mathrm{Am}$ phacanthus oramin $(=S$. canaliculatus $)$, the sexes may be readily distinguished and separated. The males are generally smaller than the females. These observations suggested a possible significant body depth variations among sexes. Moreover, Al Ghais (1993) recorded heavier weights for females than for males in relation to length.

$K$ values are usually used to indicate the suitability of the environment and to compare between wild and reared fish.

The present work detailed information about $S$. canaliculatus oogenesis and spermatogenesis processes are of great value for artificial spawning of the species and could serve as applicable technical basis for fry production in the hatchery in the near future. Apparently, spawning in captive S. canaliculatus is influenced by the moon phase (El Sayed and Bary, 1994). This species mature 1-2 months earlier in captivity than in nature (Bwathondi, 1986). The development stage of the oocytes when the fish were transferred to spawning tanks was more important. Histological evidence indicated that only those fish with oocytes characterized by germinal vesicle migration spawned without injection. Successful breeding and mass rearing of $S$. canaliculatus to metamorphosis were carried out (Manacop, 1937, Mcvey, 1972, Bryan et al., 1975, Akatsu et al., 1984 and Tawada, 1991).

Several investigators have recently demonstrated that some rabbitfishes can be grown to commercial size in various types of culture systems including earthern ponds (Pillay, 1990 and Tawada, 1991), cages (Baga and Scayanan, 1980; Bwathondi, 1986; Tacon et al., 1990 and Kunguankij et al., 1990) and tanks (Paul et al., 1990). Under commercial conditions (cages or ponds) growth rate was at least twenty times higher than in smaller tanks. Comparable results for S. rivulatus was 140 $\mathrm{g}$ for the same period (Shalaby, 1998). S. luridus showed a faster growth rate than $S$. rivulatus and it may prove to be worthwhile to put more effort into developing it as a fish culture candidate. No competition exist between the two species when grown together (Shalaby, 1998). It is important therefore, to collect more data on the possibility of polyculture $S$. canaliculatus, $S$. rivulatus \& S. luridus. Since previous farming trials of raising $S$. rivulatus with mullets and prawn in Saudi Arabia were successful (Bukhari et al., 1989). There, the culture of "Safi arabi" must be considered as being potentially highly attractive. Not only fish can be reared (from wild caught seed) to a market size of about $150 \mathrm{~g}$ in 8-9 months, but it also can be cultured at densities of up to 150 fish / $\mathrm{m} 3$ with no risk of cannibalism. Furthermore, rabbitfish have the ability to feed on a wide variety of low cost and locally available animal feed lines in dried form, including their ability to keep algal net fowling to a minimum through their continuous browsing activities. Floating net cages, covered above water with bamboo matting appears to offer the best prospect for successful farming of rabbit fish (Lam, 1974 \& Tacon et al., 1990).

a) Detect the possible relation between size (Body depth ratio index) and sexual dimorphic growth, a very useful character for sexing the species visually under aquaculture conditions. 
b) Derive formulae representing the relationship between total and standard fish length so as a valid comparison between results based on either length could be made.

c) Describe the state of well being (robustness) of males and females $S$. canaliculatus using the condition factor and signify differences if any.

d) Identify these three important diagnostic characters (BD, SL \& K) for two siganid species, $S$. canaliculatus and S. spinus, inhabiting midArabian Gulf.

\section{References}

Al-Aradi, J., Al-Baharna, W. and Al-Alawi, Z. (1985) Feasibility of rearing Siganus oramin (Siganus canaliculatus) in closed system in the State of Bahrain, Proc. Symp. Coastal Aquaculture, 3: 933-940.

Al-Ghais, S.M. (1993) Some aspects of the biology of Siganus canaiculatus in the southern Arabian Gulf, Bull. Mar. Sci., 52(3): 886-897.

Akatsu, S., El Zahr, C. and Al-Aradi, J. (1984) Egg and larval development of Siganus Bull. Mar. Sci., 5: 1-10.

Bryan, P.G., Madraisau, B.B. and McVey, J.P. (1975) Hormone induced and natural spawning of captive Siganus canaliculatus (Pisces: Siganidae) year round, Micronesica, 11(2): 199-204.

Daghestani, F.A., Abu Shusha, T.L. and Kalantan, M.Z. (1988) Fishes of Saudi Arabia Kingdom from Red Sea and Arabian Gulf Waters, Report Min. Agric. and Water Fish Res. Cen., Jeddah, 114 p. (In Arabic).

EI Sayed, A.M. and Bary, K.A. (1994) Life cycle and fecundity of rabbitfish Siganus canaliculatus (Teleostei: Siganidae) in the Arabian Gulf, Oebalia, 20: 79-88.

Helfman, E.S. (1968) Preliminary observations on the Teuthidid (= siganid) fishery in Palau, Unpublished Report, dated June 1968, $7 \mathrm{p}$.

Jayasankar, P. (1990) Some aspects of biology of the whitespotted spine-foot, Siganus canaliculatus (Park, 1797).

Lam, T.J. (1974) Siganids: Their biology and mariculture potential, Aquaculture, 3: 325-354.

Lazarus, R.J. and Reddy, P.S.R. (1986-87) On the little known rabbitfishes Siganus javus and $S$. canaliculatus (Pisces: Siganidae), A perspective of length-weight relationship, Matsya, 12-13: 26-33.

Manacop, P.R. (1937) Artificial fertilization of dangit, Amphacanthus oramin (Bloch \& Schnider), Philipp. S. Sc., 62: 229-237.
Marine Resources Research Centre (MRRC) (1995) Rabbitfish Culture, Report, Ministry of Agriculture \& Fisheries, Umm Al Qaiwain, United Arab Emirates.

Mohamed, N.I. (1991) Biological and Biochemical Studies of Some Siganid Fishes from the Mediterranean Waters off Alexandria, M.Sc. Thesis, Fac. Sci., Alexandria University, $215 \mathrm{p}$.

Ntiba, M.J. and Jaccarini, V. (1988) Age growth parameters of Siganus sutor in Kenyan marine inshore water, derived from numbers of otolith microbands and fish length, J. Fish Biol., 33: 465-470.

Snedcor, G.W. and Cochran, W.G. (1980) Statistical Methods, Iowa State Univ. Press., Ames, Iowa, USA., 593 p.

Tacon, A.G., Rausin, N., Kandari, M. and Cornelis, P. (1990) The food and feeding of marine finfish in floating net cages at the National Sea Farming Development Centre, Lampung, Indonesia: Rabbitfish Siganus canaliculatus (Park), Aquaculture and Fish. Management, 21: 375-390.

Tawada, S. (1991) Rabbitfishes (Siganus sp.), In: Aquaculture in Tropical Areas, S. Shokita, K. Kakazu, A. Tomori and T. Toma (eds.), Midori Shobo Co. Ltd., Tokyo, pp. 114-126.

Thobaity, S., Bokhari, F. and Badawi, A. (1984) Cultivation of Siganids in the Red Sea, Report Min. Agric. and Water Res., Saudi Arabia, 71 p (in Arabic).

Wassef, E.A. and Abdul Hadry, H.A. (1996) Growth of rabbitfish Siganus canaliculatus Park (F: Siganidae) in the Arabian Gulf near Dammam, Saudi Arabia, In: "Gutshop 96", Feeding Ecology and Nutrition in Fish Symposium Proceedings, Int. Cong. Biology of Fishes. San Francisco State University, July 14-18, 1996, pp. 145148.

Wassef, E.A. and Abdul Hady, H.A. (1997) Breeding biology of rabbitfishes Siganus canaliculatus Park in mid Arabian Gulf, Fish. Res., Amsterdam, 33: 159-166.

Wassef, E.A. and Abdul Hady, H.A. (1999) Amino acids and fatty acids profiles of pearl spotted rabbitfish Siganus canaliculatus (Park) muscles (Pisces Siganidae), Bull. Nat. Inst. Oceanogr. Fish., 25: 357-370.

West, G. (1990) Methods of assessing ovarian development in fishes, A review, Aust. J. Mar. Freshwater Res., 41: 199-222.

Woodland, D.J. (1983) Family: Siganidae, In: FAO Species Identification Sheets for Fishery Purposes, Fishing Area, 51 (W. Indian Ocean), Fischer, W. and Blanchi, G. (eds), prepared by FAO, Rome, Italy (Pages variable). 
بعض الدراسات البيولوجية على نوعين من أسماك الصافي من الخليج العربي السعودية

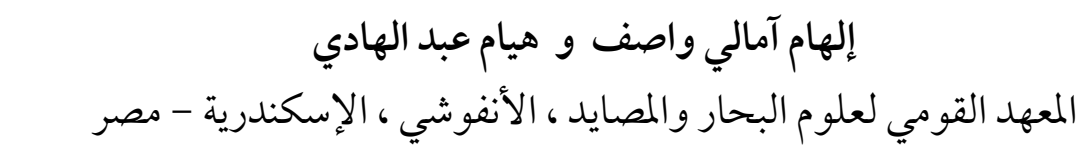

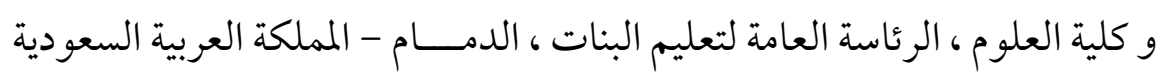

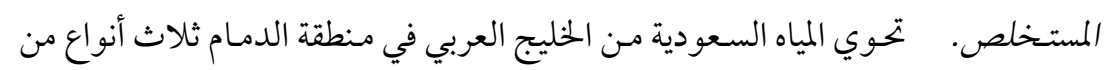

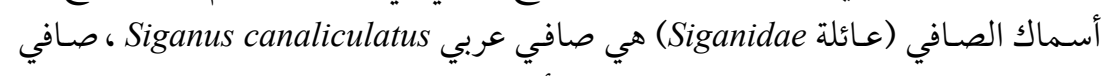

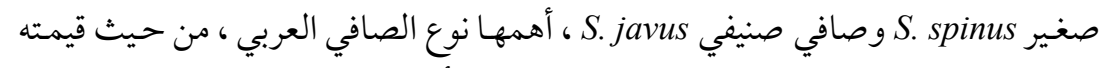

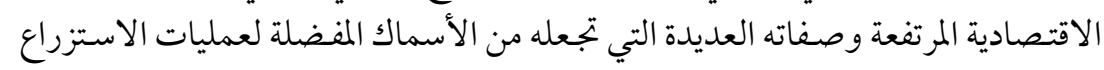

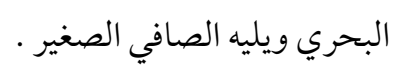

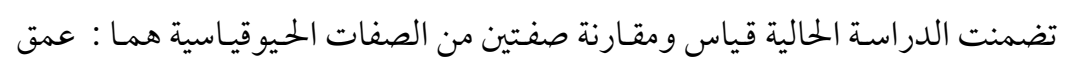

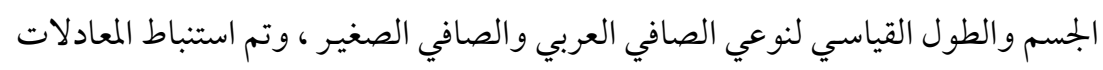

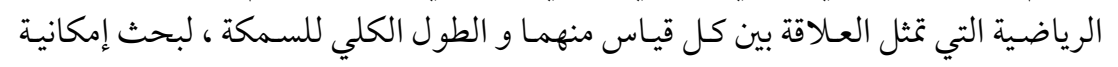

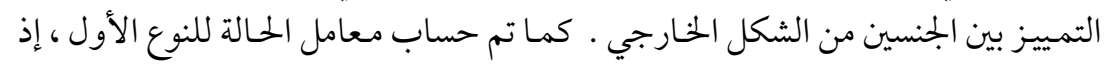

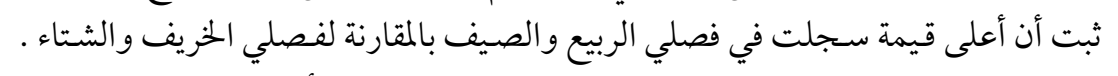

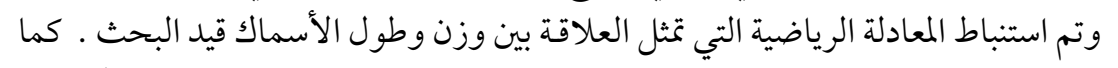

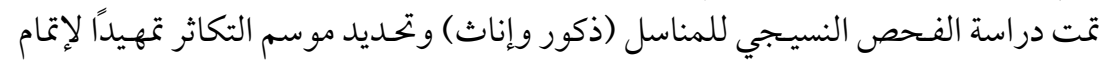

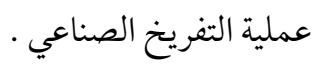

